\title{
Survey of Zijes Written in the Subcontinent
}

\author{
S M Razaullah Ansari*
}

(Received 23 June 2015)

\begin{abstract}
The basic religious duties of a Muslim, and their compliance are carried out using astronomical time reckoning, geographical location and also observation of lunar crescent. In fact the observance of these duties compelled the Islamic scientists to incline themselves to the reception of astronomy and mathematics as developed in the neighbouring countries of Arabia. The knowledge thus gained was developed enormously, particularly in the field of observational astronomy.

A $Z \bar{i} j$ (plural $Z \bar{j} \bar{a} \bar{t}$ in Arabic) is actually a compilation of astronomical- mathematical tables for calculating the position of Sun, Moon and planets particularly. It may contain also a catalogue of stars. Besides these some Zījes have also a geographical gazetteer. Zījes are also used for predicting the occurrence of solar and lunar eclipses. Evidently Zījes are aid to observational astronomy and consequently the essential task of an astronomical observatory. Although in early centuries of Islamic Middle Ages, Zïjes were written in Arabic - we mention a couple of them in the introduction - in the later centuries Persian became the medium of their compilation.

In this paper, we present a survey of Zījes compiled in the erstwhile Indian subcontinent. Two

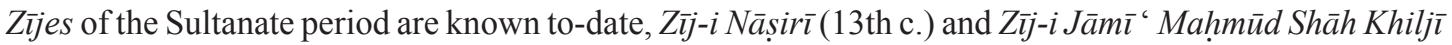
(15th c.). In the Mughal period, eight Zijes appear to be compiled according to our present knowledge. The most significant Zījes were Zīj-i Shāh Jahānī (AD 1629), Zìj-i Muhammad Shāhī (1719), and Zij-i Bahādur Khānī (1838).Tracing their historical origin, we discuss their contents.

Another class of Zījes based on Indian Siddhāntic astronomy — in contrast to the above-mentioned Zijjes based on Graeco-Arab or Islamic astronomy - were also compiled in the subcontinent. We have discovered nine such Zījes, which have been listed here only. For details of these Zījes, Ansari (2009b) has to be referred.

The paper contains two appendices for a list of manuscripts libraries and six text citations listed in Persian script.

Key words: Astronomical tables, Islamic practical astronomy, Islamic astrology, Mathematical tables, Siddhāntic astronomy, Observatories, Zīj.

\section{INTRODUCTION}

Three basic religious duties (arkān) are to be discharged by every Muslim, 1. Five Prayers (Șalāt in Arabic, Namāz in Persian) are observed daily, the times of which are defined according to the rules of astronomical time reckoning (' $\mathrm{Ilm}$ al-

$M \bar{l} q \bar{a} t)$, that is by determining the position of the sun in the sky during daytime and of certain stars at night. 2. While praying Muslims face towards $K a$ ' $b a($ Qibla $)$ - the room at the center of the Grand Mosque in Mecca - and therefore mosques are to be oriented accurately towards $K a^{\text {' }} b a$.
\end{abstract}

\footnotetext{
* Former Professor of Physics, Aligarh Muslim University, Aligarh 202002 (India), Former President of International Commissions for Science and Technology in the Islamic World, and of Ancient and Medieval Astronomy.

E-mail: Raza.Ansari@gmx.net
} 
Evidently, calculating its direction from any terrestrial location is a problem of mathematical geography, which is solved by spherical trigonometry. 3. The sighting of the lunar crescent (Hiläl) at sunset, by which begins the first day of every month of the Islamic calendar. Evidently this sighting depends on the position of the sun, moon and also their positions with respect to the local horizon. The solution of all these problems can be carried out quite accurately using mathematical sciences, particularly astronomy. ${ }^{1} \mathrm{As}$ a consequence of observing these religious injunctions, Islamic scholars began an intensive and extensive reception of natural sciences in the first few centuries of the spread of Islam (8th 9th c.). A multitude of scientific works from Babylon, India, Iran and Greece were translated into Arabic. This transmission had an official sanction as well. Beginning with the reigns of Umayyad Caliphs and particularly during the reigns of the Abbasid Caliphs al-Mansūr (754775), Hārūn al-Rashīd (786-809) and al Mā'mūn (813-833), the transmission of foreign or ancient sciences achieved its climax. During those times, Sassanian, Indian and finally Greek astronomy and mathematics were acquired in Arabic translations and assimilated. Thus the writings of great scholars were produced. Some of these are al-Khwārizmī (9th c.), al-Farghānī and al-Battānī (9th-10th centuries), Ibn Sīnā, Ibn al-Haytham and alBīrūnī (11th c. ), Nașīruddīn al-Ṭūsī (13th c.), to name just the most important Islamic scientists.

In the context of this scenario, one can understand the emphasis particularly on the observational astronomy as developed in the Islamic countries (hereafter Islamic astronomy) . Even in the early Abbasid period (750-850), astronomical observatories were established, in which practical astronomy was carried out quite diligently. The earliest observatories, the Shammāsīya and Qāsīyūn observatories, both were founded by Abbasid Caliph al-Mā'mūn (d. 833), the resulting observatory movement culminated in the establishment of an Observatory at Marāgha (Iran) in 1259 (Director, Nașīruddīn Ṭūsī), another Observatory at Samarkand in 1420 (founded by Sultān Ulugh Bég) and the Observatory at Istanbul in 1575-1577 (Director, Taqī al-Dīn Muhammad). ${ }^{2}$ Those observatories (Rasad Khāne) and even observational stations by individual astronomers were evidently furnished with naked eye instruments, with the help of which practical/observational astronomy was carried out, for instance the measurement of the obliquity, the rate of precession, the eccentricity of the solar orbit, position of the solar apogee, planetary conjunctions, observations and prediction of solar and lunar eclipses etc. In fact the primary task at these observatories was the compilation of $Z \vec{i} j$ (plural Zijāt), a handbook of sort. These Zījes were essentially astronomical-mathematical tables employed to determine particularly the position of Sun, Moon, and various planets. All Zijjes, in Arabic, Persian, Hebrew and Turkish, contain also tables for trigonometrical functions and functions of spherical astronomy. They deal also with the following topics: solar and lunar parallax and their eclipses, lunar visibility, gazetteers, star catalogues and tables of ascendants for astrological purpose. ${ }^{3}$ To overview $Z \vec{i} j$-literature, we may refer to the pioneering survey first by Kennedy (1956), an updated interim report by King and Samso (2001), and the comprehensive $Z \bar{i} j-S$ urvey of about more than $200 Z \bar{l} j$ es by Benno van Dalen (2007), to be published soon.

In this essay we wish to present sufficient details of $Z \bar{y} j e s$, which were compiled in Persian and in the erstwhile Indian sub-continent during

\footnotetext{
Cf. King ( 1993), chapter I and II.

2 See for details Sayili (1960) chapters II, VI and VIII.

3 The uninitiated reader may consult the excellent essay "The Scope of the Zỉj-Literature” by King and Samso( 2002), pp. 497508.
} 
the Medieval period ${ }^{4}$ : the Sultanate period (12th15 th centuries) and the Mughal period which began with the dynastic rule of Zahīruddīn Bābur (reigned 1526-1530), followed by reigns of Humāyūn (r. 1530-1556), Akbar (r. 1556-1605) etc., ${ }^{5}$ and ended in 1857 with the dethroning of emperor Bahādur Shāh by the British East India Company. Both Sultans and particularly Mughal emperors were very keen to patronize scholars from the Central and West Asia. Those scholars ('Ulam $\bar{a}$ ' in Arabic), including also mathematicians and astronomers, thronged to the courts of Sultans, Emperors and even the local rulers and nobles ('Umarā'). In fact, the scientists in them brought various scientific, particularly mathematical and astronomical texts; for instance the writings of Nașīudīn Ṭūsī (d. 1274) of Marāgha, Sulțān Ulugh Bég (d. 1449) of Samarkand, and Bahā'uddīn al-'Āmilī (d. 1622), to name just a few. ${ }^{6}$ That the scientific classics then available in India even during the 12th century and its familiarity by Indian intelligentsia is corroborated by the Quatrain $\left(R u b \bar{a}^{\natural} \vec{\imath}\right)$ composed in Persian by the famous Indian poet Mas ' $\overline{\mathrm{u}} \mathrm{d} \mathrm{Sa}^{6} \mathrm{~d}$ Salmān (born in Lahore in 1054, d. 1121 ). He wrote a panegyric in the praise of heir apparent Abul Qāsim Sayf al-Dawlah Maḥmūd in AD 1076 -77. A free paraphrase of his composition is as follows (Salmān, pp. 332-333),

“All astrologers ... predicted, using $Z \bar{l} j-i$ Battānī, that the kingdom of Sayf al-Dawlah would be proclaimed by the sermonizers of the seven climes [i.e., all over the world] and 50 years ago Abū

\begin{abstract}
Rayhān [al-Bīrūnī ] professed in his Tafhīm that in the year 469 [A.H./1077 A.D] a king would be born as the 'Lord of Conjunction' [of the auspicious stars]."
\end{abstract}

For the original text of the $r u b \bar{a}^{\natural} \bar{l}$, see the Appendix II (Persian Text), A1. Now Muhammad al-Battānī ( d.929) compiled his Zīj-i Șābī in about AD 912, while Abū Rayhạn al-Bīrūnī (d. 1073) wrote his Kitāb al-Tafhìm li Awā'il Șinā'a alTanjīm ( The Book of Instruction in the Elements of the Art of Astronomy) in Ghazna in AD1029 .8 This versified composition indicates clearly that important astronomical works written just a couple of centuries earlier were already transmitted to Indian Subcontinent, were even available in the beginning of the 12th century, and that they were quite popular then in general among the Indian intelligentsia: the poets, scholars and even stateadministrators (Dabīr). ${ }^{9}$

\section{ZiJes of the Sultanate Period ${ }^{10}$}

\subsection{Zīj-i Nāṣirī (ZN)}

According to our present knowledge, this is the first Indian $Z \bar{i} j$ of the Sultanate period of Indian History, written by Mạmūd ibn 'Umar alRāzī, who dedicated it to Nāṣiruddīn Maḥmūd bin Sultan Shamsuddīn Iltutmish, who ruled in Delhi during 1246-65. ${ }^{11}$ According to Storey ( pp. 7475), "its unique manuscript had been extant in Ḥusayn Āgha Nakhjawān̄̄ Library (Tabriz)"; it

\footnotetext{
4 The present survey is substantially revised and updated version of those published earlier by Ghori (1985) and Ansari (2013).

5 Note that during the reign of Emperor Muhammad Shah (r. 1719-1749), Rajah Jai Singh got built observatories in five Indian cities, and he sponsored a $Z \vec{i} j$ also. See section 3.4.

${ }_{6}$ For the transmission of astronomical texts in India, see Ansari (1995), esp. Appendix I, p.288 et seq.

7 Sayf al-Dawlah was the title of Abul Qāsim Maḥmūd son of Ibrāhīm, who was the fourth son of Mas 'ūd bin Mahmūd Ghaznawī. In AH 469 / AD 1077, he came to India as Vice-regent.

8 See Bibliography for full references.

9 See Ansari (2008a), also Ansari (1995). We may mention that Salmān's composition was first noted and cited by Ghori (1969), p. 13.

${ }^{10}$ In the sequel, references to the libraries/collections are denoted by symbols, which are listed in Appendix I.

${ }_{11}$ Ansari (2008a), p. 62; Ghori (1985), pp.30-31.

${ }^{12}$ The famous Iranian scholar, Taqizādeh (1938, p.245, f.n.280) writes that the owner of that manuscript sent him a couple of excerpts from that manuscript. It indicates that the manuscript existed, when Taqīzādeh was writing on Calendar in Ancient Iran.
} 
does not seem to exist now. ${ }^{12}$ Moreover, an Indian Parsi scholar, Mullā Fīrūz, copied an excerpt from that manuscript ( of about 2 pages), and which in turn is extant in the Library of CRL (Bombay). ${ }^{13}$ The title of the excerpt is as follows, "On the Calculation of the True Solar Longitude (Taqwìm) from $Z \bar{\imath} j-i$ Nạsir $\vec{\imath}$ ". For some details see Ansari (2008a, pp. 62-63). Fortunately we have been able to find another complete manuscript of this $Z \vec{j}$, in the ANM Library (Qum), Ms. 9176, comprising $165 \mathrm{ff}$., copied close to the time of the author.$^{14}$ Noteworthy is also that $Z N$ is No. 72 in the list of 86 Zījes, given by Emperor Akbar's chronicler Abū'l Faḍl 'Allāmī in his $\bar{A}$ ' $\bar{l} n-i$ Akbari ${ }^{15}$ It indicates that it was available in India in the sixteenth century also.

In the first rukn ('pillar') on fol.111a, 65 fixed stars (Thawäbit) are cataloged for the year 615 Yazdigird (AD 1247) with their longitudes and latitudes. In one of his numerical examples (fol.10b) the given date is Thursday 22 Sha'bān AH 641 (4 Feb. AD 1244). The author's base meridian is Delhi. In fact, his numerical examples lie mostly between AD 1235-1245, during which time Mahmūd ibn 'Umar evidently had been compiling his $Z \bar{i} j$. In other words this first Indian $Z \bar{i} j$ was compiled even before Nașirudīn Ṭūsī's Zīj-ī Ilkhānī (AD 1271).

In his introductory folios the author Ibn 'Umar al-Rāzī mentions his 30-year study of earlier Zijes, compiled by practical astronomers.
He lists names of 15 astronomers with whose works he became familiar; they were Hipparchus, Ptolemy, al- Battānī, al-Ṣūfī, al-Bīrūn̄̄, alKhāzin̄ī, al-Shīrwānī ( alias al-Fahhād, the author of $Z \bar{l} j$ al- 'Alā' $\bar{l})$ etc., in all 14 compilers of Zījes.

His $Z \bar{i} j$ consists of two rukn (divisions), the first of which contains tabulated material for detailed calculations of heavenly bodies in 66 chapters (120 ff). The second rukn ( paginated afresh) deals with the theory or general principles of astronomy, illustrated by direct calculation without recourse to tables; it consists of 60 chapters (44 folios). The topics dealt are, chronology, functions of trigonometry and spherical astronomy, planetary positions, conjunctions and eclipses, astrology, geographical tables. According to a comparative study by Dalen (2004, p.831), "the mean motions were calculated with very high accuracy and these tables of $Z N$ agree with $Z \bar{l} j$ al- 'Alä' $\bar{l}$ (Persian version)". ${ }^{16}$

After the table of contents of the first rukn, Mahmūd ibn 'Umar begins his $Z \bar{l} j$ with a short discussion on various calendars ( $t \bar{a} w \bar{a} r \bar{\imath} k h)$ under chronology as customary in all $Z \bar{l} j e s$. He defines the beginning (epoch) of an era, names the first day of the first year, nomenclature of the months with number of days and the total number of days in a year. The calendars are: i. The Persian Yazdigird (beginning on Tuesday). ii. The Islamic Hijrī (cites the beginning on Thursday after Muhammad Jābir Harrān̄i, and on Friday after

\footnotetext{
${ }^{13}$ Rehatsek, p.27, Ms. No.47.

${ }^{14}$ See Husaynī and Mar'ashī, Catalogue of the Library, XXIII, p. 293. We acknowledge Dr. Mar'ashī Najafī for presenting us with a copy of this unique manuscript.

${ }^{15}$ For the list of these 86 Zījes, see Ghori (1985), appendix, pp.41-47. Cf. also Abdullah Zade (1986-87) for comments on some of those Zījes.

16 'Abd al-Karīm al-Fahhād al-Shīrwānī wrote Zīj al-'Alā' $\bar{l}$ al-Raṣadī in Arabic in ca. 1175/76, the Persian version of which was carried out by Shams al-Dīn al-Bukhārī, under whom a Greek scholar Gregory Chioniades studied in Tabrīz in 1295/96. Later Chioniades prepared in Constantinople (now Istanbul) its Byzantine Greek version which is extant; the edition of its Greek text

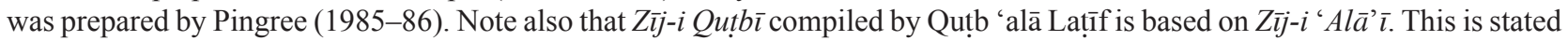
clearly by the author on f. 5a of the unique manuscript, autograph of AD 1584, see the Catalogue of SJM Library (Hyderabad), Ms. No.3881,Vol. IX, p. 233.Moreover, it is No. 65 in the list of Zījes by Abū'l Faḍl 'Allāmī, who named the compiler as Fakhruddīn Abul Hasan 'Alī bin Karīm al-Shīrwānī, also known as al-Fahhād. These examples show that Zỉj-i 'Alā' $\bar{l}$. was extant in the 16th century in India.
} 
Ahmad bin 'Abdullāh al-Habash). iii. The Roman Antinnash (beginning on Monday). ${ }^{17}$ Our author notes that Ptolemy has used this calendar for the catalogue of fixed stars in his Almagest. iv. Aghastas (beginning Friday). ${ }^{18}$ However, according to al-Hāshimī ( 9th c., p.113), the beginning was on Thursday. Mahmūd mentions that Christ was born in his times. v. Dhulqarnayn (beginning Monday). ${ }^{19}$ The authors notes that alBattānī employed this calendar for the planetary motion in his $Z \bar{l} j$. vi. Faylqūs [Philip] era (beginning on Sunday), the author mentioned that he was the descendant of Prophet Ishāq. vii. Bukhtanasar [Nabonassar], beginning on Wednesday. This era was used by Ptolemy for planetary motion. viii. Țüfān I (flood), beginning on Friday, ${ }^{20}$ and used by Abū Ma'shar al-Balkhī for mean motion of planets. ix. Tārikh-i 'Ālam. Mahmūd defines it as the era when all planets started their motion from the First Point of Aries. In the second rukn, he discusses the Jewish and Hindu $(h u n \bar{u} d)$ years and notes specifically that the calendar of India, "śaka kāl is the most famous one" (fol. 4b-6b). In passing we may add that the author tabulates a gazetteer of 199 towns on folios $32 \mathrm{~b}-34 \mathrm{a}$ according to climes (Aqālìm). However, the entry of the longitude of Delhi $104^{\circ} 29^{\prime}$ (on fol. 33a) seems to be wrong, the correct value $103^{\circ} 35^{\prime}$, which is given on the opposite page (fol. $32 \mathrm{~b}$ ). His base meridian (mawda $a^{6}-i$ rasad) is Delhi. ${ }^{21}$

\subsection{Z̄̄j-i Jāmī‘ Maḥmūd Shāh Khiljī (ZJ)}

The unique copy of this anonymous $Z \bar{i} j$ is extant in Bodleian Library (Oxford), catalogue No.
1522, Ms. Greaves 6, with 104 folios. John Greaves (1650) 22 published the Persian text with Latin translation of the preface and the first section ( $f a s l$ ) of the first chapter $(b \bar{a} b)$ of the Persian Text. It comprises elements of geometry and spherical astronomy with glossary of terms in Arabic/ Persian particularly.This Latin version has been translated into English and thoroughly commented by Young (2004).

Since the first page of the $Z J$ is missing in the manuscript, the name of the author is not known. The text consists of an introduction (muqaddima), two chapters ( $b \bar{a} b$ ), and an epilogue (khātima). Unfortunately the manuscript is not complete, for it ends with the first chapter. That is, the second chapter and the epilogue is missing. The colophon is written at the end of the first chapter, "Here ends the book, Zīj-i Jāmī' Mahmūd Shāh Khiljī by the weak hand of Mawlānā Fiṭr 878 " (i.e., $1474 \mathrm{AD}$ ). This title is given only here and not anywhere else in the text. In the Catalogue of the Bodleian Library the title is $Z \bar{i} j-i$ Intikha $\bar{b}$, meaning thereby that the text is a selection from many $Z \bar{j} j e s$. Note that its only commentary or extract carries the title, Dar Istikhrāj-i Taqwìm az $Z \bar{l} j-i$ Muntakhab (On the Calculation of ephemerides from 'Selected $Z \bar{i} j$ ' ) extant in M.S. King's College, Cambridge (England). ${ }^{23}$

The introduction (muqaddima) comprises 36 sections, in which the following topics are treated. Elements of astronomy beginning with the definition of observations (rasad) and $Z \bar{l} j$, elements of geometry and of arithmetic of sexagesimal system used in astronomy, definitions of astronomical terms in particular, and finally

\footnotetext{
${ }^{17}$ It is after the King Antonius Pius, who reigned during AD 138-161.

${ }^{18}$ Roman Emperor Augustus son of Phillip II ruled during 31-14 BC.

${ }^{19} \mathrm{He}$ is Alexander the Great, King of Macedonia, who ruled during 356-323 BC.

${ }^{20}$ The epoch date of this era is Feb.18, 3102 BC, the year of which is known also in ancient Indian astronomy as the beginning of Kālì Yūga.

${ }^{21}$ For other technical details cf. Dalen (2004) and also Dalen (2007), p.146.

${ }^{22}$ John Greaves (1602-1652) had been Savilian Professor of Astronomy (1643-1648) at Oxford. He was considered to be an expert of Persian language and its grammar; for further details see Young (2004), p 503, note 5.

${ }^{23}$ Cf. the Catalogue Browne Supplement, No. 655, p.106, cited in Storey, p.75, and Dalen (2007), p. 146.
} 
treatment of the astrolabe in 12 sections. Then the author begins his chapter I. It is divided into 22 sections. It suffices to name here the various calendars, In the first section, he treats the theory of calendars, followed by a section each on calendars of Hijrī, Rūmī (Byzantine), Yazdigird (Persian), Malikī, method of converting dates of one calendar into another, the Turkish (ChineseUighur), which is quite lengthy having 11 subsections (qism) and the Jewish calendar. In the last 10 sections, the authors discusses the determination of the longitude and latitude of Sun, Moon, planets, their conjunction and opposition, lunar and solar eclipses, and 2 sections on astrology and its problems. ${ }^{24}$

As usual in $Z \bar{i} j$-literature, this work is also dedicated to the Indian ruler, Sultan of Mālwah Maḥmūd Shāh Khiljī (reign 1436-1469), ${ }^{25}$ hence its title. The author began writing his $Z \bar{i} j$ first in AH852/ AD1448 in Cairo at the request of some nobles, left it for some time and took it up again in AH865/ AD1461. He then traveled to India in AH866 AH /AD1462, the year in which his native town Bidar was conquered by the Sultan ${ }^{26}$ under whose order he resumed the writing of his $Z \bar{l} j$. Curiously enough, the name of the ruler is not given in the manuscript copy, the place is left blank. For further details of this short autobiographical note and other matters of the Persian text, see the first study of ZJ by Wright and Wiedemann (1926-27), Storey (1972, pp.7475), Ghori(1985, pp.31-32), and van Dalen (2007, pp. 145-146). Finally, we may mention that the author of ZJ praises particularly one of its source, Nașīuddīn Ṭūsī's Zīj-i Îlkhānī, completed in AD $1271,{ }^{27}$ but he has not referred to Zilj-i Ulugh Beg, completed in AD1440, which probably was not available to him .

\section{Zĩjes of the Mughal Period}

It may be recalled that Emperor Babur (prior to his conquest of India) had forged an alliance with Shāh Ismā ‘̄il I of Persia and Emperor Humāyūn had bonded a friendship with his son Shāh Tahmāsp (d.1576). Consequently, even during the following reigns of Mughal Emperors, Akbar (d.1605), Jahāngīr (d.1627) and Shāhjahān (ruled 1627-1658), the cordial relationship with Safavids rulers, viz., Shāh 'Abbās I (d.1629) and Shāh 'Abbās II (d. 1666), strengthened further. ${ }^{28}$ In this perspective the following interesting story is to be appreciated. Shah 'Abbās I sent to Emperor Jahāngīr as gift the original astrolabe of Ulugh Beg - founder of the observatory and a madrasa at Samarkand. However, the Shah kept for himself only its copy. Friendship a galore! Another noteworthy gift by the Shah was a large ruby inscribed with the name of Ulugh Beg, and which was presented to the then prince Khurram (later title Shāhjahān) by the Iranian ambassador in about $1620-21 .{ }^{29}$ It is therefore not surprising that already during emperor Akbar's reign, the transmission of Ulugh Beg's school of astronomy to Medieval India was initiated and contributed

\footnotetext{
${ }^{24}$ Ghori (1985), p.32.

${ }^{25}$ For a short history of the Sultan, see Nurul H. Ansari’s study of Ma'āthir-i Mahmmūd Shāhī (1968). The author of this Persian text is actually 'Alī ibn Muhammad al-Kirmān̄̄, the manuscript of which is in Bodleian Library (Oxford), Ms. Elliot 237.

${ }^{26}$ It is known that Farishta Sultan Mahmūd Shāh started a campaign to subdue Deccan in AH 866 /AD1462. According to the historian, Sultan Mạ̣mūd Shāh, " gave great encouragement to learned men and founded several Colleges [madrasahs] in different part of the Kingdom for the promotion of literature"; Farishta Briggs, pp. 118, 136.

${ }^{27}$ That the author has used Tūsî̀'s $Z \bar{l} j$ is corroborated by the positions of apogee given for the epoch year 818 Yazdigird/ AD 144849( fol. 101b) which agree well with those of $\bar{l} l k h \bar{a} n \bar{\imath} Z \bar{j} j$, Dalen (2007), p.146.

${ }^{28}$ Riazul Islam (1970), preface.

${ }^{29}$ Cf. Riazul Islam (1970), pp. 72, 80. For the latter information Riazul Islam quoted Tūzuk-i Jahāngīrī, translated by Rogers and edited by Beveridge, Vol. II, pp. 195-196. For the relevant Persian text, see Appendix II-A2, from Ṭāhir Khān/ 'Ināyat Khān( p. 212), who described the King's throne, studded with gems and jewels, in which one of the jewels was that gifted one, costing one lakh Indian Rs. [in 17 th c. AD].
} 
to the further development of astronomy and mathematics in general on the erstwhile Indian sub-continent. ${ }^{30}$

The first most important work of the above-mentioned school was the compilation of $Z \bar{i} j-i$ Ulugh Beg (hereafter as ZUB). ${ }^{31}$ To note is that during the reign of Emperor Akbar, a team of Muslim and Hindu scholars under the leadership of Mīr Fathullāh Shīrāzī (d. 1589) had been commissioned to translate this $Z \bar{l}^{32}$ into Sanskrit. ${ }^{33}$ A manuscript copy of such a translation is extant in CPM (Jaipur). ${ }^{34}$ Evidently $Z U B$ became very popular in India. Interestingly a page autographed by Ulugh Beg and dated AH 848 /AD1444 is attached with its manuscript in SJM (Hyderabad). ${ }^{35}$

According to our survey about 50 copies of this $Z \bar{l} j$ are extant in manuscript libraries of India and Pakistan even today. Noteworthy is that almost all Indian $Z \bar{i} j e s$ written in the 16th century and thereafter were modeled or styled upon $Z U B$; for

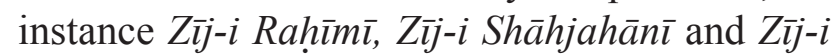
Muhammad Shāhi . We give in the sequel some details of these Zījes. We discuss also a commentary on Zỉj-i Ulugh Beg, written by Mullā
Chānd, the court astrologer of emperors Humāyūn and Akbar. ${ }^{36}$

For readers to appreciate this basic $Z \vec{i} j$, the topics and brief contents of its chapters are mentioned below. ${ }^{37} Z U B$ consists of four Discourses (maqālas). ${ }^{38} \mathrm{I}$. On chronology and calendars: The Hijrī, the Faylqūs ( or Philip) era, the Yazdigird, Malikī or Jalālī and ChineseUighur, and their conversions into one another. ${ }^{39}$ II. On the mathematics of the trigonometrical functions and their interpolation. Note particularly tables for sine and tangent functions, based on the calculation of Sine $1{ }^{\circ} .{ }^{40}$ III. It deals with the theory of planetary motion, Sun and Moon, calculation of their positions, and contains also a catalogue of 1018 fixed stars (Thawābit). The epoch of the latter is AH 841 / AD 1437. However, the year of compilation of the $Z U B$ is AD1444; cf. the discussion by Dalen (2007, p. 97). IV. On astrology.

\subsection{Tashīl-i Zīj-i Ulughbegī}

This commentary ( Tashīl) on $Z U B$, rather a simplified version, was written by Mullā Chānd ibn Bahā'uddīn, who was the astrologer-

\footnotetext{
${ }^{30}$ Ansari (2009a).

${ }^{31}$ The edition of its Persian text was published by Sédillot (Paris 1847), and its French translation with commentary also by him (Paris 1853). However, the most comprehensive commentary (161 pp.) was published with Russian translation of the text by Ashraf Akhmedov (Tashkent 1994) at the occasion of the 600th Birth Anniversary Conference of Sultan Ulugh Beg (13941449), see details Khairullaev et al. (1994). We thank Ashraf for presenting us a copy of his publication.

${ }^{32}$ Cf. Abū'l Faḍl/ Blochmann, Part I, p. 34, footnote 1, for details. Fathullāh's expertise in rational sciences was recognized, since he had been the pupil of Ghiyāthuddīn al-Manșūr Shīrāzī who wrote a tract on the Rectification (Taṣhīh) of Zỉj-i Ulugh Beg and also a commentary on Almagest of Ptolemy, cf. Rosenfeld and Ihsanoğlu (2003), No. 963, p.322, and for Fathullāh, No. 1023, p. 341 .

${ }^{33}$ Abū'l Faḍl/ Blochmann (Tr.), Part I, p. 110.

${ }^{34}$ Cf. Bahura ( 1971), pp.58-59. Ms. No. 45. It was acquired from the city of Surat by Raja Sawā'i Jai Singh in 18 th century.

${ }^{35}$ Ms. No. H41 in Salar Jung Museum Oriental Library (Cat.Vol. IX, No. 3861, p.224) with the following sentence in Persian: “Katbah warqah Ulugh Beg bin Shāh Rukh bin Tïmūr Gürgān fì sinha DMMH'. The last three letters denote the year AH 848 in abjad notation.

${ }^{36}$ For other commentaries on ZUB extant in India, see Ansari (1995), p. 293.

${ }^{37}$ For details of contents, see van Dalen's preliminary Survey(2007), pp. 97-100 (revised version forthcoming).

${ }^{38}$ See details in the Rosenfeld and Ihsanoğlu's Catalogue (2003), pp. 278.

${ }^{39}$ This first maqāla was also translated into Latin by John Greaves and published with Persian text in 1650 AD. It has been reprinted with an introduction (muqaddimah) by Farid Ghassemlou( Tehran 2008). We thank him for a copy.

${ }^{40}$ For the determination of Sine $1^{\circ}$, see Rosenfeld and Hogendijk (2003). The paper contains the edited Arabic text, with English translation and annotations. Its PDF can be downloaded from the web page of Prof. Hogendijk (Utrecht). See also Rosenfeld and Ihsanoğlu's Catalogue (2003), entry M1, pp.278, for other works concerning Sine $1^{\circ}$.
} 
astronomer both at emperor Humāyūn's court and later also at emperor Akbar's court. He is known to have prepared a horoscope of Akbar (b. 25 Oct. 1542 AD), ${ }^{41}$ and also the horoscope of Jahāngīr (b. 30 Aug.1569). ${ }^{42}$ A unique copy of this simplified $Z \bar{l} j$ is extant in the CPM(Jaipur), Ms. (Arabic and Persian) No.6. The manuscript bears the seal of one 'Abd al-Khāliq ("a slave of Shāh Jahān"), dated AH 1038/A.D. 1628-29. To note is that this Tashīl by Mullā Chānd is mentioned by Farīduddīn in his Zīj-i Shāhjahānī and also by Raja Swā'i Jai Singh in Zīj-i Muhammad Shāhī. ${ }^{43}$

Mullā Chānd has more or less followed $Z U B$ in the presentation of the text of his $Z \vec{i} \vec{j}$. For instance, he has also divided his text into three Maqālas, containing the usual topics: chronology, ${ }^{44}$ on functions of trigonometry and spherical astronomy. At some places he has inserted a chapter or two for making the contents easily understandable. At the end of each maqāla, he added tables, which are updated version of the corresponding tables of the $Z U B$, because of the passage of time of more than 150 years between the compilation of original $Z U B$ and Tashīl.

\subsection{Zīj-i Raḥīmī (ZR)}

Mullā Farīduddīn Mas‘ūd bin Ibrāhīm Dehlawī compiled this $Z \bar{i} j$ and dedicated it to his patron Mirzā 'Abdur Rahīm Khān Khānān (d. AH1036 / AD1627 ). ${ }^{45}$ The unique copy of $Z R$ is extant in the Central Library of the Holy Shrine of Radawī, Ms. No. 5554., with 441 folios ; but the manuscript is incomplete. ${ }^{46}$ It ends after the few tables of planet Saturn, with no colophon evidently. On the fly page the cataloger noted the name of the bequeather (wāqif) Mirzā Raḍā Khān with the year AH1311/ AD1893. As Mullā Farīd tabulated the equation of time ( $\mathrm{Ta}^{\circ} \mathrm{d} \overline{\mathrm{l}} \mathrm{l}$ al-Ayyām) for the Sun and Moon for the year AH1026 / AD1617 (ff. 152b, 153a), it appears that he might have been compiling $Z R$ around that year. According to one historical reference, Mullā Farīd had been in the service of Khān Khānān till AH1024 /AD1615 and thereafter as well. ${ }^{47}$

Farīduddīn Munajjim (astronomer), as he was usually called, had been a pupil of Mīr Fathullāh Shīrāzī — an expert of $Z U B^{48}$ — from whom he learned rational sciences ('Ulüm-i 'Aqliya) including astronomy and astrology. Consequently, $Z R$ is modeled on $Z U B$. That is, it comprises also an introduction (muqaddima), and four maqālas. The former is further divided into four sections (qism). To note is that the author explains two kinds of Zījes. 1. Rasadi (observational), 2. Hisābi (calculated). Briefly stated, he explains the former as that based on observations of the experienced scholars and practical astronomers, who, using theoretical principles and instruments, determine the positions of stars and their motion in longitude and latitude,

\footnotetext{
${ }^{41}$ Ghori (1985), p. 33. Ghori's chapter is the first study of this Zīj. This horoscope was reproduced by Abū'l Faḍl in his $A k b a r n a \overline{m a}$, Vol. 1, pp . 56-57.

${ }^{42}$ Akbarnāma, Vol. 2, pp.506-507.

${ }^{43}$ For these two Zijjes, see sections 3.3 and 3.4 respectively.

${ }^{44}$ Contrary to $Z U B$, he did not stress much the Chinese-Uighur calendar in this Maqāla.

${ }^{45}$ Khān Khānān was the Chief of Army Staff (Sipāh Sālār) of emperors Akbar and later also of his son Jahāngīr; of whom he had been also the teacher (Atālīq) before. During emperor Shāhjahān's reign he was the governor of Gujarat state. He is said to be a scholar of many languages, Arabic, Persian, Turkish and also Hindi / Sanskrit. He was a poet also and had translated the Tüzak-i Bābari from Turkish into Persian in 1590. He is known to have patronized many scholars ('Ulamā') and founded a number of madrasas; cf. Shāhnawāz Khan /Ayyūb Qādrī, Vol. 1, p. 689 et seq.

${ }^{46}$ See the Catalogue of the Library by Fikrat, p. 299. We thank Dr. Mohammad Bagheri for providing us with a copy of ZR.

${ }^{47}$ Ghori (1985, p. 34 ) quotes the history of Shahjahan’s reign, 'Amal-i Ṣaliḥ by Muḥammad Ṣāliḥ Kunboh, Vol. I (1960), p. 361. Note that Ghori has wrongly conjectured that $Z R$ is identical with another tract of Farīduddīn, Sirājul Istikhrāj, a manual of (astronomical) calculations written in AH 1006/ AD1598.

${ }^{48}$ See, note 32 above.
} 
their magnitude, direction and distance from each other with respect to Earth. On the other hand, the second kind is meant to correct by calculations the discrepancies and changes occurring during the course of time, for instance, in the mean motions etc., and entered in $Z \bar{\imath} j-i$ Rasadi together with mistakes introduced by scribes copying the manuscripts (fol.2a,b). ${ }^{49}$ Thereafter Farīduddīn eulogizes " the nearest of his times, most trustworthy and accurate $Z \bar{\imath} j-i$ Rasadi compiled by Mirzā Ulugh Beg" (fol. 2b, line 7-9), and explains the structure of his tables and treats the various calendars, which are: Hijrī, Faylqūs (or Philip) era, Persian or Yazdigird, Malikī (attributed to Sultan Jalāluddīn Malik Shāh Saljūqī), calendars of Chinese (Qat $\bar{a})$ and Chinese-Uighur, the last one he uses for his tables of solar equation (fol. 9a). In maqāla II, he explains first only the basic concepts and therefore his various chapters and sections are short and to the point. There is also a section on the transformation of one calendar date into another.

Farīduddīn gives also detailed tables of trigonometrical functions, sine and tangent (ff. 2139), tables for solar declination (mayl awwal), second declination (mayl thān $\bar{l}$ ), right ascension and oblique ascension for the latitudes of Samarkand, the capital town of Akbar Ābād (now Agra), Lahore etc. For the time reckoning he gives tables for Samarkand, Indian city of Burhānpūr, Lahore etc. Strangely enough he calls Samarkand as the place of observation (Mawda $a^{6} i$ Rasad).

He lists the geographical longitude and latitude of 325 cities ( ff. 109b, 110 a,b), copied from Taqwìm al-Buld $\bar{a} n^{50}$ etc. The table on ff.111a,b contains 238 entries, and it is stated clearly that these entries have been copied from $Z U B$. We find that a number of Indian cities are listed, e.g., Daulatabad, Lakhnotīi (now Lucknow), Jaunpūr, Ajmer, the capital Agra, capital of India Dehlī (Delhi), Kol-Jalālī (now Aligarh), in all about a dozen cities.

To sum up, Farīduddīn has followed initially $Z U B$ in style and contents, but in his tabulated material a large number of tables have been added in order to simplify (Tashīl) the calculation of ephemerides (Taqwim) of Sun, Moon, and Saturn. In fact, the author has clearly explained two methods for the calculation, by not using or using Tashill; in the latter case the interpolation between the entries of a table are not required (ff.113b, 114a). As mentioned above, the manuscript ends abruptly on fol. 227 with the table for the first equation of Saturn, reckoned from the zodiacal sign Gemini (Jawzā').

\subsection{Zīj-i Shāhjahān̄̄ (ZShJ)}

Farīduddīn Munajjim had been also an author of a couple of other writings besides $Z R$. Sirājul Istikhrāj (Lamp of [astronomical] Calculation) is one of them. The title is a chronogram, but adding only the numerical values of its dotted letters : $\boldsymbol{j}(3)+\boldsymbol{t}(400)+\boldsymbol{k h}(600)+\boldsymbol{j}$ $(3)=1006$, according to abjad notation. That is, it was written in AH1006/AD1598, when he joined the services of Khān Khānān, to whom he dedicated this tract on astronomical calculations. In fact, he appears to be quite well known as an astrologer also besides an astronomer. For instance, he prepared the horoscope of Sultan Ibrāhīm 'Adil Shāh's son, born in AH1022 /AD 1613, the manuscript of which is extant in Berlin. ${ }^{51}$

\footnotetext{
${ }^{49}$ See the Persian text in Appendix II- A3.

${ }^{50}$ The Damascene geographer Abu'l Fidā Ismā‘īl al-Ayyubī (d. 1331) wrote this treatise "A Sketch of Countries", in Arabic between AD 1316-1321. In 28 chapters the author dealt with problems of mathematical and physical geography, and included a gazetteer of cities. The book has been translated into Latin, French, German and Russian. See Calvo ( 1997), p.7, where further references are given. Cf. also Rosenfeld and Ihsanoğlu, No. 680, p. 237.

${ }^{51}$ Storey ( 1972), p. 89. Sultan Ibrāhīm 'Ādil Shāh II ruled Bījāpūr during 1580-1627, to whom the historian Farishta dedicated his History of India by the subtitle, Gulshan-i Ibrāhīmī ( Garden of Ibrāhīm).
} 
Here we are interested in his major astronomical work, another $Z \bar{l} j$, dedicated to emperor Shāhjahān, whose court he joined just about Emperor's coronation in 1627. The complete title is, Kārnāmah-i Sạhhib Qirān-i Thānī, Züj-i Shāh Jahānī ( Great Work of the Second Lord of the Conjunction, Shahjahan's $Z \bar{i} j$ ). Here the ceremonious title of the Emperor refers to the auspicious conjunction (Qirān) of Jupiter and Venus at the time of his birth on 5 Jan. 1592 in Lahore. ${ }^{52}$ The $Z \vec{i} j$ was completed in AH1039 / AD1629-30, but the epoch year is AH 1041 / AD1631-32. The former date is corroborated by the report of 'Abdul Hamīd Lāhorī, the emperor's chronicler, in his Pādshāh Nāmāh. Reporting the event of AH1039 / AD1629-30, it is said, ${ }^{53}$

\begin{abstract}
“... During [those] days the Zīj-i Hisābi known as $Z \bar{u}$ j-i Shāh Jahāni was completed by the unique [authority ] of the times Mullā Farīd with the collaboration of his brother, Mullā Tayyab, and other astronomers, and particularly with the best efforts of Yamīn al-Dawlah Āsaf Khān. ... In view of its many benefits and [containing ] numerous principles and rules, [the Emperor] ordered that it should be translated into the language of Hindustan by Indian astronomers in consultation with Persian astronomers, for the sake of public utility. Although before this $[Z \bar{i} j]$ the ephemerides were calculated using $Z \bar{i} j-i$ Ulugh Begi , now [they] could be deduced easily from this $Z \bar{i} j$."
\end{abstract}

See the Persian text in Appendix II-A4. This statement is true. Pandit Nityānanda, the Hindu court astronomer of Shāhjahān, translated in $1630 \mathrm{ZShJ}$ into Sanskrit. One manuscript copy of this Sanskrit Text with the title Siddhantasindhu is extant in the Maharajah Man Singh Museum, Jaipur. Three more copies are available in the Royal collection (Khāsmohor).
It is known today that out of 14 manuscripts of ZShJ in world libraries, 5 mss. are extant on the erstwhile Indian subcontinent. They are in the manuscripts libraries in Lahore (PUL), Hyderabad (SCL), Rampur (RL), and Jaipur with two copies: one scribed by Jagan Lekhaka (scribe), under the order of Amīr Āssafjāh, the second one acquired through Hākīm Mīsī Zamān Khān. Both copies were acquired in 1725 by Sawa'i Jai Singh. ${ }^{54}$ In passing it may be added that in one Sanskrit Ms. (No.5484, Khāsmohor collection, Jaipur), the lunar theory of $Z U B$ is compared with that of $Z \bar{\imath} \vec{j}-i$ Shāh Jahānī. It shows that ZShJ had been studied also by an astronomer of Jai Singh.

We may add some details of the contents of ZShJ. Its chapterisation is the same as in $Z U B$, i.e. one introduction (muqaddima), and four discourses (maqālas). Each maqāla is divided into many chapters (bāb); a chapter is further divided into sections (qism or fasl). The introduction is similar to Farīduddīn's $Z R$, defining the $Z \bar{\imath} j-i$ Rașadi, and $Z \bar{l} j-i$ Hisāb $\bar{\imath}$ and discussion thereof etc. The chapter on calendars /eras comprises the usual Hijrī, Rūmī (Byzantine), Yazdigirdi (Persian), Malikī, and Chinese-Uighur, but with the addition of Indian calendar, Shākha Sālbāhan (Śāivāhana Śakha in Sanskrit). Following the suggestion of his patron Așaf Khān, he has also included the modified Ilāh $\bar{\imath}$ calendar of Akbar, ${ }^{55}$ by beginning it from 1628, the regnal year of Shāhjahān, thus calling it Tārīkh-i Ilāhō Shāhjahānī. The remaining chapters are copied almost verbatim from $Z U B / Z R$. However, the number of tables far exceed those of $Z U B$. For instance, at the end of the second maqāla, the

\footnotetext{
${ }^{52}$ Thanks to Dr. R.C. Kapoor (Bangalore) who has kindly checked this statement and found that both planets were in the same zodiacal sign Scorpio on 5.1.1592. We may add further that the First Lord of the Conjunction (Sahib-i Qirān) refers to Sultan Amīr Tīmūr (born on 8 April 1336). Then Jupiter and Mars were in conjunction, i.e. both were in the zodiacal sign of Taurus, as quoted by Orthmann (2005), p. 111, note 35. Actually both emperors were very proud of their time of birth, when auspicious conjunctions occurred.

${ }^{53}$ Ṭāhir/ 'Ināyat Khān, p. 82.

${ }^{54}$ For further details, see Rosenfeld and Ihsanoğlu (2003), p. 358, and Dalen(2007), pp. 147-148,

${ }^{55}$ Tărīkh-i Ilāhì was proclaimed by emperor Akbar in 1584. This calendar was devised by Mīr Fathullāh Shīrāzī. Its epoch began from the regnal year 1556 of Akbar ( Akbar Nāma, Vol. 2, p. 17). See also note 84 below.
} 
tables are spread over 68 folios, and the third maqāla comprises 319 folios. ${ }^{56}$ In other words, the tables of ZShJ are not confined to the basic tables but contain also auxiliary tables for the sake of simplification, as in $Z R$ or in any commentary on a $Z \vec{i} j$. The epoch year of $Z S h J$ is AH1041/163132.57

\subsection{Zīj-i Muhammad Shāhī (ZMS)}

It has been reported that emperor Muhammad Shāh (reign 1719-1749), on the advice of his astrologer Mubashshir Khān, ordered Mirzā Khairullāh to prepare a new $Z \bar{\imath} j$, so that the discrepancies arising in the astrological calculations due to the use of 300-year old ZUB might be eliminated. Consequently the Emperor commissioned Raja Sawā'i Jai Singh to get a modern (Jadīd) Zīj compiled by Mirzā Khairullāh, which when used by Mubashshir Khan did not show any discrepancy. ${ }^{58}$

Following the traditional $Z \bar{l} j$-style particularly of ZUB, this $Z \bar{i} j$ comprised three discourses (maqālas), each of which consists of various chapters. ${ }^{59}$ The fourth maqāla of ZUB on astrology was not included. The first maqāla is on chronology or calendars, consists of four chapters, each of which is devoted to one era (Tārīkh), the Hijrī, Muhammad Shāhī, Christian (' $\bar{I} s w \vec{l})$ and Indian (Samvat or Sanpat). To note is that the Chinese-Uighur calendar dealt in $Z R$ and $Z S h J$ has been completely left out, which was evidently not useful for the Indian astronomers. Emperor Muhammad Shāh reigned during 17191748. His regnal year (Sāl-i Julūs) is 1719. Months of the calendar named after him are same as of Hijrī calendar, but its year does not begin (Mabdā') from the month of Muharram, rather from Monday $1 \mathrm{Rab}^{-}$' II, $1131 \mathrm{AH}$ / Feb.20, 1719 (Gregorian). Note that this is also the epoch or beginning position of all mean motion tables in $Z M S{ }^{60}$

The second maqāla comprises 19 chapters, in which the trigonometry, spherical astronomy and particularly determination of ascendants for various latitudes are dealt with.This Maqāla is verbatim reproduced from $Z U B$. However, the section on the "Direction of Qibla" has been left out. At the end of this Maqāla are geographical tables, giving longitude and latitude of a few hundreds Indian and foreign towns. ${ }^{61}$

The third maqāla comprises an introduction (muqaddima) and four chapters, in each of which the determination of mean motion of Sun, Moon and planets is discussed with the help of relevant tables. In the epilogue (khātima), the problems of calculation of lunar and solar eclipses, visibility of lunar crescent (ru'yat), and the occultation of planets have been treated. Finally $Z M S$ ends with a catalogue of fixed stars for the year $1138 \mathrm{AH} / 1725-26 \mathrm{AD}$; the ecliptic longitude were obtained by adding $4^{\circ} 8^{\prime}$ to the corresponding longitude of stars listed in Ulugh Beg's star tables.

Here we may point out a few special features of ZMS. Most probably ZMS had been prepared in two stages. Its first and second maqālas are based solely on Zīj-i Ulugh Bég. ${ }^{62}$ These Maqālas might have been composed before

\footnotetext{
${ }^{56}$ Ghori (1985, p. 35) noted for the first time this feature in ZShJ Ms. Or. 372 in British Museum.

${ }^{57}$ Cf. Dalen (2007), No. H6, p. 148.

${ }^{58}$ Sangīn Bég (1816/1982) reported this information in his book (pp.117-118), under the entry Jantar Mantar, a folk name for Jai Singh's observatories. The word 'Jantar' is derived from 'Yantar', which means 'instrument'. The actual Persian text is cited in Appendix II-A5.

${ }^{59}$ Ghori (1985) listed the headings of various chapters.

${ }^{60}$ Cf. Dalen (2000), section on epoch position, p.43 et seq. See also his historically interesting endnote 4 in this connection.

${ }^{61}$ This number varies in different mss., e.g., 135 in Aligarh Ms., 300 in Majlis Ms., and 600 in Lahore Ms. See details about the extant manuscripts at the end of this section.

${ }^{62}$ Ghori(1985, pp. 36-41) gives details of the contents. Pingree (1987, pp.323-324) has compared the various sections of ZMS with ZUB in details.
} 
ca. 1730-1731 AD,when Sawa'i Jai Singh's delegation /embassy returned from Portugal to India, bringing several Europeans books, including de La Hire's astronomical tables. ${ }^{63}$

The third maqāla, which was revised or freshly prepared, is based on the astronomical tables of the French astronomer Philippe de La Hire (d. 1718). ${ }^{64}$ It is actually a mixture of some translated tables and others, particularly those of the mean motions of Sun, Moon and planets derived from de La Hire's Tables for the epoch position of ZMS, Feb. 20, 1719 (Gregorian) and for the longitude difference of Delhi and Paris. Dalen (2000) has analyzed the tables of all mean motions in ZMS and thereby determined the actual method of computation of mean motions by the astronomers of Jai Singh. ${ }^{65}$

As for the planetary system, ZMS contains the geocentric planetary model but with elliptical orbits. The following quotation from the commentator Ghulām Husain Jaunpūrī clarifies sufficiently well this model of ZMS. ${ }^{66}$

"The preceding and modern astronomers supposed that the eccentric orbs [of heavenly bodies] were circles and on the basis of which they calculated their equations. [However] Mirzā Khairullāh Muhandis asserted in his Commentary to ZMS that he found the orbit of Sun and actually of all bodies as elliptical. On the basis of the former [hypothesis], the calculated equations of sun and all planets did not agree with the observations. On the other hand, when the equations were calculated according to the latter, they were found to agree mostly with the observations, hence the orbits must be elliptical".

Jaunpurī then elaborated the mathematics of this model further in his Encyclopaedia of Sciences. ${ }^{67}$ It may be pointed that Jai Singh and his astronomers were not unique in accepting this geo-heliocentric model of planetary motion. There exists a whole history of such models, till finally the Copernicus' version of heliocentric system with Kepler's hypothesis of elliptical orbits was accepted as depicting the reality of the solar system. ${ }^{68}$ Noteworthy to mention here is that the most important prose translation into Sanskrit ordered by Jai Singh was the tract, Phirangicandra-cchedyakopayogika (Aid to Representation of the European Lunar Theory), which faithfully reproduced the heliocentric

\footnotetext{
${ }^{63}$ On Jai Singh's Indian delegation to Portugal/Europe, which was headed by Jesuit Fa. Emmanuel de Figueredo, see Sharma, V.N. ( 1982), pp. 335-337. For a brief account of Jai Singh and his connections with Jesuit astronomers, see Ansari (1985b), pp.371-375.

${ }^{64}$ Mercier (1984) was the first to study this question. See also Mercier (1993), who commented on the Frenchman Joseph Dubois' 3-page Preface to the transcript of La Hire's Tables ( Latin edition of 1727), which is extant in Jai Singh's Library at Jaipur. According to Dubois, Jai Singh ordered Persian translation of La Hire's tables. However this statement should not be understood as evidence of verbal translation of La Hire's tables always. For instance, the tables of mean motions of planets in ZMS are not copied from La Hire's corresponding tables, see explanation to this point in the sequel above. Cf. also Forbes (1982, pp. 235-238) who has assessed the astronomical works of Philippe de La Hire, and discussed especially the critical reception of his Tables by Jai Singh and his astronomers. We may mention here that Jai Singh did order one of his astronomers, Kevalarāma, to translate La Hire's Tables into Sanskrit. The Dṛkakșasāraṇ̄ (Tables for Observational Astronomy) was in verse form and represented the first Sanskrit translation of La Hire's lunar theory, see Pingree (2002a).

${ }^{65}$ Note that Dalen $(2000$, pp. 51, 64) has used his own devised statistical method, for the study of mean motions and planetary parameters in general. I thank him profusely to comply with my wish to undertake this study.

${ }^{66}$ See Ghori (1980, p.55), who was the first to point this feature. The original reference is Ghulām Husain Jaunpūrī, Encyclopaedia of Sciences, p.579. On Jaunpūri and short introduction to his works, see Ansari and Sarma (1999/2000). See also the following section 3.5 here.

${ }^{67}$ For details of special study of Jaunpuri's treatment, refer to late Rizvi (1989).

${ }^{68}$ For instance the mathematician Francois Viète (d.1603) modified Ptolemy's model by replacing the epicycles and deferents by epi-ellipses and elliptical deferents before Kepler who suggested the elliptical orbits in 1609. Ansari (1985, pp. 368-369) has summarized the historical discussion on this point, and noted that the effect of heliocentric theory even in the 16th century Europe was not much pronounced and it was not even mentioned in text books (ibid f.n. 47). The original reference is Schofield, chapter IV, "Seventeenth Century Debate over the World Systems", pp. 168 et seq.
} 
diagram of de La Hire, along with the explanation that a planetary orbit was a Keplerian ellipse. The Sanskrit term used for "ellipse" is matsyakara, meaning "having shape of the fish", see David Pingree (2002 b, p. 129) for details.

Another special feature of ZMS is Jai Singh's mention of having used telescope for observing planets and stars during day time. We summarize below Sawā'i Jai Singh's own words given in the chapter, "Visibility of the Crescent" of the third maqāla. He says, ${ }^{69}$

“....Telescopes were constructed in my Kingdom, and with their aid I see bright and luminous stars even at mid-day in the middle of the sky. By their help I see [also] the new moon even before the time calculated by astronomers for the emanation of its rays, and after it enters the prescribed limit of its invisibility. The same is true regarding the appearance and disappearance of the remaining five planets and also with the rising and setting of lunar mansions..."

See the Persian text, in Appendix II-A6. The following observations by using a telescope are then enumerated: i. The phases of Mercury and Venus. ii. The existence of Sunspots and their rotation. iii. Jupiter with its four satellites and bands. iv. The ellipsoidal shape of Saturn. v. The slight motion of the [so called] fixed stars with different velocities. ${ }^{70}$ We have found this passage about the telescopic observations in almost all manuscripts of ZMS available to us. Besides, diagrams corresponding to the first four observations are drawn on the margin of a folio in manuscripts extant in Bombay, Cambridge, Lahore, Patna but not in the Ms. of British
Museum. We have found even a selenographic diagram of the lunar surface in one Ms.in CRL (Bombay). See these diagrams in Fig. 1a,b reproduced from Ansari (1985a, p. 381). ${ }^{71}$ It does not lie in our purview to discuss further here why Jai Singh did not use his telescopes for all of his observations and why did he confine himself to measurements by means of his masonry instruments, since these questions have been discussed at length elsewhere. ${ }^{72}$

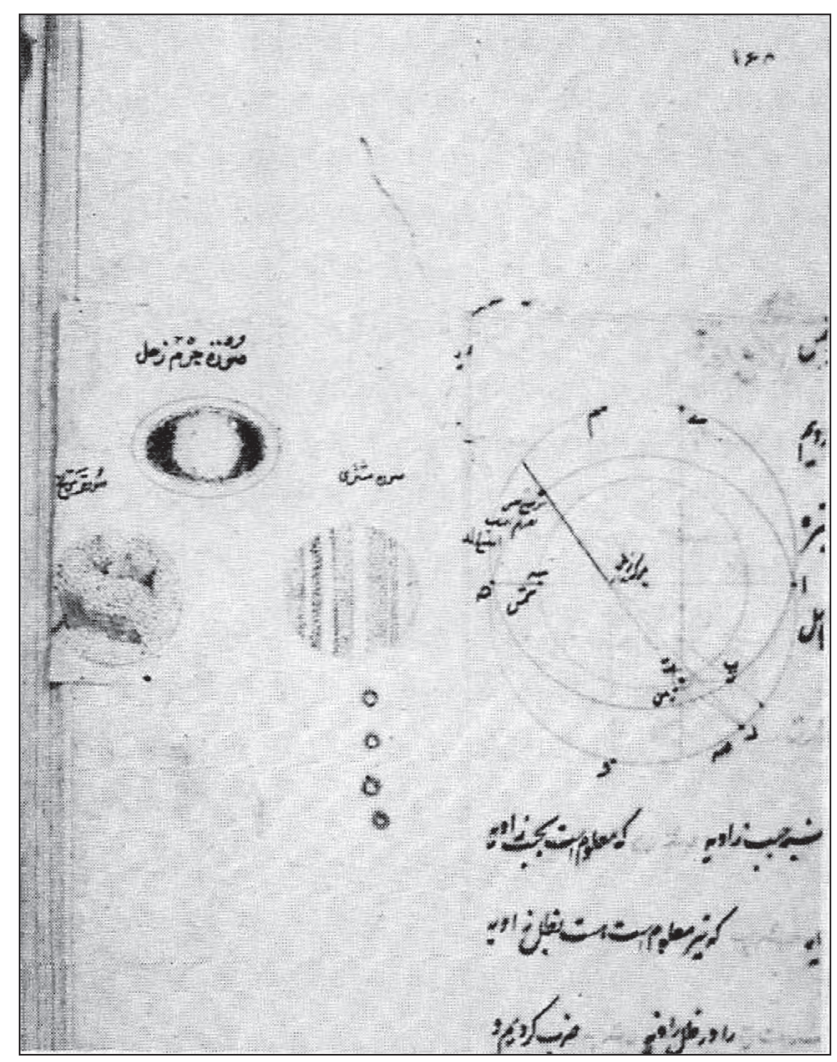

Fig. 1a. ZMS (Bombay), diagrams of Saturn with rings, Jupiter with bands and 4 moons, and Mars with markings

\footnotetext{
${ }^{69}$ Ms.No.30, fol. 81, Aligarh Muslim University (Persian Collection) in M.A. Library.

${ }^{70}$ See Ghori (1980, pp. 55-56) who translated the actual Persian text into English.

${ }^{71}$ Ansari (1985a, pp.380 -383) wherein Jai Singh's observations with the telescope of his own making have been dealt with and on p. 381 photographs of the drawings of the planets from the Ms.RI-53 of ZMS (in Mulla Firuz Collection, K.R. Cama Research Library, Bombay) have been reproduced.

${ }^{72}$ Cf. Ansari (1985b, pp.364-367)), the section on the use of telescope, where the lack of micrometer and cross wires in Jai Singh's telescope(s) has been discussed thoroughly. See also the discussion on the the use of telescope in general as an observing device in Europe on pp. 366-367. It is sufficient to cite the words of van Helden (1974, p.42), “... During the first twenty five years of its existence, the telescope remained primarily an instrument for terrestrial use, .... When one turned such an instrument to the heavens, it was usually to see for oneself the discoveries of Galileo...".
} 


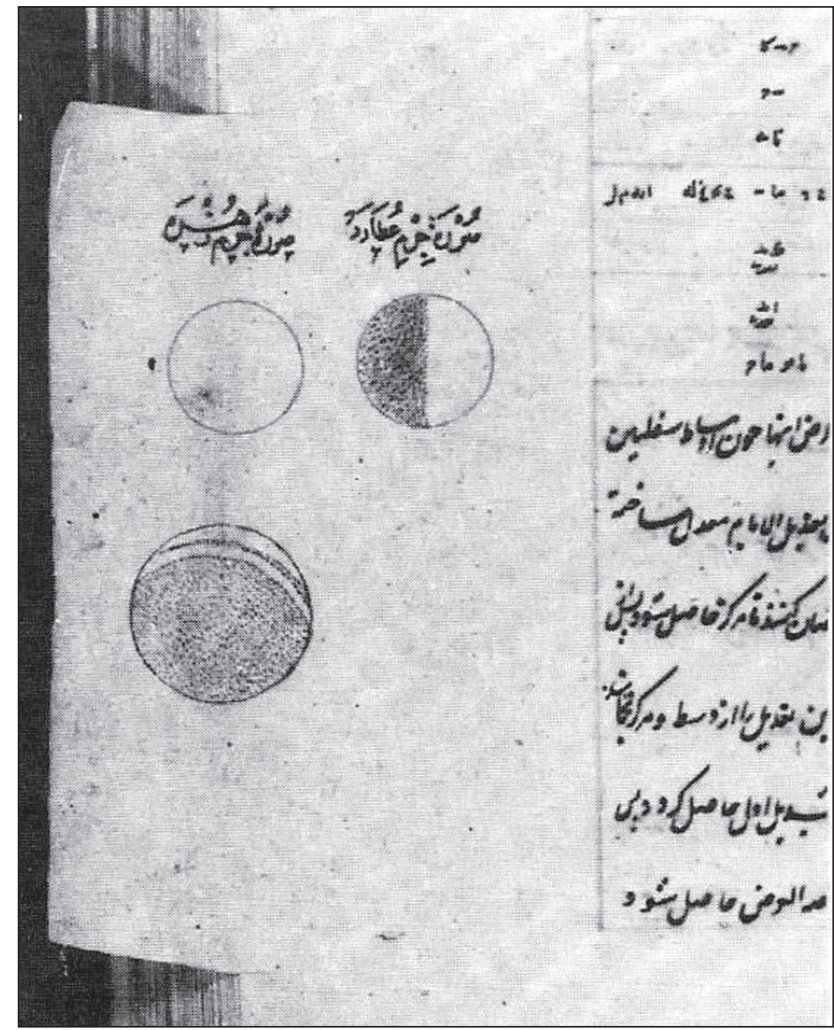

Fig. 1b. First row, Mercury (on right), Venus (on left). Second row, Venus with a phase (Courtesy K.R. Cama Research Library, Bombay)

Finally, a piece of information about the actual authorship of the text of ZMS may be noted. ${ }^{73}$ The Persian sources speak of Mirzā Khairullāh Khān (d. 1747) s/o Luṭfullāh Khān ${ }^{74}$ (d. 1682) as the actual compiler of $Z M S$, whereas traditionally the authorship is attributed to the sponsor, Raja Jai Singh, who was actually commissioned by Mughal Emperor Muhammad Shāh " to get a new $Z \bar{l} j$ prepared by Mirzā Khairullāh Khān", as quoted in the beginning of this section above, see also Appendix II-A5 for the Persian text. As further evidence, we confine ourselves to cite only the following. i. Muhammad 'Alī, the scribe of the copy of ZMS ( Ms. 2144, fol. 105a, in the Majlis Library, Tehran), clearly stated that his father Khairullāh, one of the astronomers of Jai Singh, was the author of ZMS. An identical note is also given in Ms. 2752, fol. 239b, extant in the Institute of Oriental Research Library (Tashkent ). ii.The Iranian astronomer and commentator, Mubashshir Khān, a contemporary of Khairullāh Khān, came to India to study under Khairullāh the ZMS and its method of calculations. He then wrote a commentary on ZMS ( unique Ms. No. 6447 in the Majlis Library, Tehran, scribed in 1884). He eulogized Khairullāh in this commentary and ranked him as a great astronomer equal to Mullā 'Alī Qūshjī (d. 1474), the actual author of Zīj-i Ulugh Beg.

To note is also that ZMS became very popular not only in India and Pakistani libraries but through out the world. Rosenfeld and Ihsanoğlu (2003, p. 400, No. 1322) list 40 manuscripts of ZMS through out the world. Our recent survey of the extant manuscripts( including one by Dalen, 2007) is as follows: 13mss. in Indian and Pakistani libraries, 32 mss. in Iran, 13 mss. in Central Asia ( 6 each in Dushanbe and Tashkent, 1 in Kazan), and 2 mss. in England, making a total of 60 manuscripts. ${ }^{75}$ However, the earliest extant manuscript copy to-date, discovered by us, is scribed by Ḥudūr llāhī Kāshmīrī, dated 1775 ; Sawā'i Jai Singh died in 1743. It is in the library of the Institute of Oriental Studies (Tashkent), Ms. No. 2752. This is the base manuscript for the critical edition of the ZMS Persian text by Ansari. ${ }^{76}$ Actually $Z M S$ was used quite extensively; it almost replaced $Z U B$ in the Subcontinent, Iran and Central Asia. Several commentaries were written on it in India, Iran and Uzbekistan.

\footnotetext{
${ }^{73}$ First reported in Ansari (2008b).

${ }^{74}$ Lutfullāh Muhandis (the architect ) was the son of Ahmad Ma'mār, who was the architect of Taj Mahal. This family of mathematicians has been well known for its contribution to mathematics and astronomy.For instance, Khairullāh has been the author of 9 works, see Ansari (2011).

${ }^{75}$ We thank Benno van Dalen for his survey of manuscripts of $Z M S$, communicated to us before publication.

${ }^{76}$ The edition is based actually on 10 mss. The English translation with commentary is under preparation. We thank Indian National Science Academy (New Delhi) for sponsoring it by a grant. The delay in the completion is deeply regretted.
} 


\subsection{Zìj-i Bahādurkhān̄̄ (ZBKh)}

This $Z \bar{i} j$ in Persian was composed in $\mathrm{AH}$ 1254 /AD 1838 by Abul Qāsim alias Ghulām Husain Jaunpūrī, on the order of Rāja Khān Bahādur Khān, to whom it was dedicated also. The exact title is Kitāb Ifāa $\bar{a} t-i$ Niṣa $\bar{b}-i \quad Z \bar{\imath} j-i$ Bahādurkhānī. (Book for Benefits in Syllabi, Bahādur Khān's Zīj), see details in the Bibliography.

Abul Qāsim alias Ghulām Ḥusain Karbalā'̄i bin Fatḥa Muḥammad Jaunpūrī was born in 1790 -91 and was taught by his father and other contemporary scholars-mathematicians. He was a court astronomer of the Rājah of Tikārī, Rājah Khān Bahādur Khān Nuṣrat Jang, son of Mahārāja Mitrjīt (or Mitrajīt) Singh, and with a Muslim mother. Tikārī is a town in South Bihar $\left(24^{\circ} 57 \mathrm{~N}, 84^{\circ} 53 \mathrm{E}\right)$ in India, where Ghulām Husain carried out his astronomical observations, according to his own testimony. ${ }^{77}$ According to one source Ghulām Husain left afterwards for Banaras (now called Varanasi) where he was appointed Chief Justice (Sadr aș-Sudūr), at the court of the Raja of Banaras. ${ }^{78}$ Later he shifted to Murshidabad to serve the Nawab there. He died on his way to his hometown Jaunpūr, at a place Dā'ūdpūr in AH 1279 /AD 1862.

We have succeeded in discovering Ghulām Husain's eight writings to-date. ${ }^{79}$ Besides the $Z B K h$, another important publication of our author is Jāmi' Bahādurkhān̄̄ (Encyclopaedia of
Sciences) written during A.D.1832 -1833 (hereafter as $J B K h$ ). It was printed lithographically in Calcutta in 1835. ${ }^{80}$ The author explains in the beginning the purpose of writing this $Z \bar{l} j$ (p.2). ${ }^{81}$

"Since the massive astronomical instruments of the Greeks (Yūnāniyān) have been rendered superfluous by the fine and accurate instruments of European scholars, a few of which are presently available in the Rājā's kingdom, we can find by observation spread over a number of years the discrepancy between the observed (Marșūdah) position of the celestial bodies and their calculated (Mahsūbah) ones on the basis of the $Z \bar{i} j-i$ Muhammad Shāhī (ZMS). And therefore we have compiled this $Z \bar{l} j$ based on our own nine-year long observations of eclipses, occultation of planets ..., so that any one [interested]can calculate, by using these tables, the longitude of the stars and planets, the occurrence of solar eclipses, crescent visibility ... year by year for a long time".

$Z B K h$ consists of one introduction (Muqaddima) and seven discourses (maqāla), each of the latter comprising several chapters $(B \bar{a} b)$. We list and discuss topics of some important discourses/chapters briefly below. ${ }^{82}$

The second maqāla on calenders (p.34 et seq.) comprises fifteen chapters, one each for each calendar: Hubūțī, Țūfānī, Coptic (Bukht Naṣrì), Rūmī ( Iskandrān̄i ), Turkish and Chinese, Indian (Samvat and Shākah Sālbāhin), ${ }^{83}$ Hijrī, Yazdigirdī, Malikī (Jalālī), European (Christian), Muhammad Shāhī, and three additional calendars, Ilāhī ${ }^{84}$, Bengali (Faṣlī), and Tughyānī. For the last one

\footnotetext{
${ }^{77}$ Cf. Jāmi ${ }^{6}$ Bahädurkhānī, p. 545, the table of ascendants for the castle of Tikārī, the table of arc of planetary visibility, again for the castle at Tikārī, pp. 632-633.

${ }^{78}$ Biographical Notices of Jaunpūr, by Khayruddīn Muhammad Jaunpūrī, completed in 1801, as quoted by Ivanov, in his Catalogue of Asiatic Society, MS. No.1490.

${ }^{79}$ For details see the article by Ansari (2007), and an updated one, Ansari (2015).

${ }^{80}$ A recent facsimile reprint of $J B K h$ has been published in 2008 by Danishgah-i Azad Islami (Tehran), with a preface by Farid Ghassemlou. We thank him for presenting us a copy.

${ }^{81}$ We shall refer here to the printed copy of the ZBKh, copy of SJM Library (Hyderabad).

${ }^{82}$ For the titles of various maqālas, see Ghori (1985), p. 43, or text of ZBKh, pp.2-3.

${ }^{83}$ Ghulām Husain distinguishes these eras and deals with them in chapter sixth and eighth respectively. For details of these Indian eras, see Chatterji and Chakravarthy (1985), pp. 299-300.

${ }^{84}$ The Ilāhī calendar began with the regnal year of Mughal Emperor Akbar, AH 963 /AD 1556, though it was actually introduced in AH 992 /AD 1584 . However, the beginning year of the Bengali calendar was taken as AD 1556. For details, see Chatterji and Chakravarthy (1985), pp. 301-302.
} 
the author says that a great flood broke out in Jamādī I, AH 1251 in his town, Sạhib Ganj (modern Gayā in Bihār), which is also the town of his observation (mawda'-i rasad). To commemorate that devastating flood, he is using it as an era, beginning Tuesday, middle of Muharram AH 1251 AH / AD 1835. In fact all his tables of planetary motions are given in Tughyān $\bar{\imath}$ years. ${ }^{85}$ To our knowledge Ghulām Husain's account of calenders is the most comprehensive one. At one place he refers to two sources, Mirāt al-'Ālam, Rawdatul Munajjimin, besides the $Z \bar{l} j-i$ Muhammad Shāhī .

The author lists also seven distinguishing features of his $Z \bar{l} j$. They are: Chapters on relevant arithmetic and mathematical astronomy, explaining the astronomical terminology, the European and Bengali calendars, tables of Indian concepts, tithis, nakșatras and karanas, tables of ascendants up to the latitude of $66^{\circ} 33^{\prime}$, i.e., not confining to $50^{\circ}$, the limit of climates (aqālim), since according to him the Europeans have crossed it. Further, his mean motion tables for Moon and planets are compiled for mean position, apogee and ascending node following $Z \vec{i} j-i$ Muhammad $S h \bar{a} h \bar{l}$. He attributes this due to their elliptical orbits ( see pp. 428, chapter on Lunar ephemerides et seq.). Ghulām Husain annexed also a catalogue of 1025 stars as given also by Ptolemy's Almagest, but up-dated for precession. However, he added a list of 11 southern stars near horizon which he observed himself with modern astronomical instruments. ${ }^{86}$

It may be mentioned that the first study of ZBKh was done by Ansari (1995/96) and its serious study is highly desirable, since Jaunpūrī had knowledge of medieval astronomy as well as of modern Western astronomy.

\subsection{Zīj-i $S a^{\dagger} \bar{\imath} d \bar{\imath}(Z S)$}

The author's full name is Muhammad Mas'ūd bin Muhammad Nasīm al-Hanafī with nom de plume (poetic name) Kāshī, who lived in the Indian city of Bareilly (northern province). To date only this much is known about him. The $Z \bar{i} j$ is dedicated presumably to his patron $\mathrm{Sa}^{\prime} \overline{\mathrm{i}} \mathrm{d}$, the title is given only in the colophon. A manuscript copy of this $Z \vec{i} j$ is extant in the Wellcome Library (London), scribed in AH 1244/AD 1828 as mentioned in the colophon fol.51b, with author's name Muhammad Amīn Mas' 'ūdī ${ }^{87}$ The name of the scribe is not mentioned. However on fol.1a, line 7-8, his full name is mentioned but without Amīn. Important to note is the following. The textspace beneath this full name appears erased to insert it, the handwriting is different from that of the scribe of the manuscript. In the colophon also the names Muhammad and Mas' $\bar{u} d$ are inserted also around the name Amīn in the same handwriting. Another name Muhammad Mas'ūd Shāh is noted on the fly leaf opposite to fol.1a, with the title Tarjamah Fārsī ( Persian translation of ) Zīch-i Mas ' $\bar{u} d \bar{l}$ (sic). It is not clear, why some one called it a translation. This note and the inserted names are in the same handwriting. Therefore it is not clear, whether the author of this $Z \bar{i} j$ is really Muhammad (Amīn) Mas' ${ }^{\mathbf{u}} d$ or not. We have found another incomplete copy with the title, Muntakhab (Selection [from] ) $Z \bar{\imath} j-i S a$ ' $\bar{\imath} d \bar{l}$, in the codex No. $3925 / 2$ in the manuscript collection of SJM (Hyderabad). It consists of 29 folios only ${ }^{88}$ For the third copy see the following section 3.7 .

\footnotetext{
${ }^{85}$ Ghulām Husain, ZBKh, maqāla II, chapter 15, pp. 57-58.

${ }^{86} \mathrm{See}$, the text of $Z B K h$, p.618. Note that Ghulām Husain was himself an instrument maker and he has written a full chapter on this topic, describing 12 instruments. Cf. Ansari and Sarma (1999/2000). To note is that a globe made by him in 1816 is extant in a private collection in Aligarh, see its description, ibid, pp. 84-86.

${ }^{87}$ This manuscript was discovered by Benno van Dalen (formerly at Frankfurt, now in Munich). This Z Zij is described briefly by him ( Dalen 2007, p. 150). I thank him for a copy of this manuscript, which is discussed here.

${ }^{88}$ See the Catalogue of SJM, p.264. Its new No. is Hay' at 42. The "Selection from ZS" is on ff.101-129. It is defective on both ends. The beginning and end start abruptly.
} 
ZS consists of an introduction (muqaddama), three discourses (maqāla) and an epilogue.The Introduction begins with the definition of various eras/ calendars (Tārīkh): the Hijri, Yazdigird, Jalālī, Byzantine $(R \bar{u} m \vec{\imath})$ and also Chinese-Uighur and Turkish eras (ff.2a-5b). Although Tārīkh-i Muhammad Shāhī is not treated explicitly, yet Muhammad Mas' ${ }^{6} \mathrm{u} d$ is aware of this calendar also. While calculating the position of the constellation Cassiopeia, he mentions using ZMS and the year 737 Jalāli/ AD 1816 (fol. 26a). The first maqāla begins on f.6a, and consists of many sections ( $f a s l$ ): on calculations of ascendants, sine and tangent functions, followed by description of elements of spherical astronomy (ff. $7 b-12 a$ ). These sections are brief, and a few relevant tables are attached at the end (ff.12b-16a). The section on gazetteer (ff.16b-18b) contains entries of 311 localities, out of which 70 are of Indian cities, and interestingly the last entry is London. ${ }^{89}$ For instance his longitude for Delhi is $103^{\circ} 35^{\prime}$ and for Bareilly city is $115^{\circ} 0^{\prime}$; using the latter he computed actually the mean positions. The second maqāla begins on f.19a and the author describes method of calculation of positions of the Sun, Moon, planets and fixed stars, also of eclipses etc. (ff.19b-26b). The text is then followed by all relevant tables( 26b-46b). In fact, the author has drawn from $Z \vec{i} j-i$ Ulugh Bég, which is his basic source for the calculation of ephemerides of the Sun, Moon, and planets. ${ }^{90}$ The third maqāla (f. $47 a)$ is on astrology. His sources for the astrological material is Ptolemy's Tetrabiblos mentioned in its beginning, Māshā'allāh (d. ca.815) and Ya'qūb al-Kindī (d.870) mentioned on fol. $48 \mathrm{a}$.

\subsection{Z̄̄JJ-i Ashkī (ZA)}

$Z \bar{\imath} j-i$ Ashkī was composed in AH 1231/AD 1816 by the poet Kundan Lal (with $A s h k \bar{l}$ as his nom de plume). The autograph copy is extant in SCL (Hyderabad ), Ms. Riyādī̄-299, 63 folios . The author's name is clearly mentioned on fol. 1b, line 7, as Kundan Lal bin Mannūn Lāl Falsafi . In fact he belonged to a Hindu family of renowned scholars of Delhi, writers and poets. ${ }^{91}$ To note is that Storey (1972, p.98, No.158) has mentioned this $Z \vec{i} j$ just by a line and Rahman et al. (pp. 322-323) have given essentially the same information as by Storey. But none of them apparently had access to the text of ZA, so as to read the colophon given at the end of the manuscript. Kundan Lāl scribed there that he "the servant of astronomers (Khädimul Munajjiminn) completed this manuscript of $Z \bar{l} \vec{j}-i S a{ }^{\prime} i d / Z \vec{i} j-i$ Amīn on Jamādī II, 1231 Hijrī corresponding to 2 May, 1816..." He quotes correctly his date also according to other calendars expertly, viz. 2127 Iskandarān̄i, 1186 Yazdigirdī, 738 Jalālī, 1873 Bikarmājīt, and 1763 Śakha. ${ }^{92}$ Similarly he mentions the time of his writing the colophon according to three schemes: local time with respect to Sun, Moon and ascendant $\left(T \bar{a} l i^{6}\right)$. Significantly Kundan Lāl does not mention any where else the author's name of ZS as given and discussed in the preceding section. On comparing several folios of both $Z A$ and $Z S$, it is clear that $Z \bar{l} \vec{j}-i S a$ ' $\bar{l} d \bar{l}$ is a copy of $Z \bar{l} j-i A s h k \bar{l}$, which precedes the former by 12 years! The use of different calendars and time reckoning schemes and also various tables cited in his $Z \bar{l} j$ is a clear indicator of the expertise of Ashki $\overline{1}$ in astronomy and therefore surely trustworthy.

\subsection{Zïj-i Maz̧hari (ZMz)}

The author is Mazharuddīn Muhammad Qārī bin Bahā'uddīn 'Alī (16th c.), probably from Shīrāz. The manuscript of ZMz belonged formerly to Urdu Promotion Board (Anjuman Taraqqi'-i $U r d u)$, Karachi. It is now in the National Museum

\footnotetext{
${ }^{89}$ Its longitude is $99^{\circ}$ (in ab jad notation $S T$ ) and latitude $51^{\circ} 0^{\prime}(N A)$, which values are not clear.

${ }^{90}$ Cf. Dalen (2007a), p. 150, who has studied its technical part.

${ }^{91}$ For the list of writings of father and son, see Ansari (2005), pp. 210-212.

${ }^{92}$ We have confined ourselves to cite here only the years corresponding to AD 1816.
} 
(Karachi). It was originally in the collection of the famous Urdu scholar, Mawlawī 'Abdul Haq (from Hyderabad Deccan), who presented it to the Urdu Promotion Board, Ms.No. $6 q \bar{a} f-f e-148$. It is dated AH 987/AD 1579 (fly leaf / f. 1a). See Fig. 2. The first two pages are missing, since the manuscript begins abruptly by listing the sixth section $(f a s i)$ of the contents. Altogether there are 12 sections ( fasl), the last is on fixed stars, which is not present in this manuscript copy. Fortunately we have found another manuscript of $Z M z$ in SJM (Hyderabad), Ms.No. US-58-4708/9 with 98 folios. According to the author of the Handlist
(Vol. XII), it was scribed by Muhammad Afụāl Burhānpūrī in AH 1191/AD 1777, at Aurangabad. To note is that Storey (Vol. II, part 1, p. 85, No. $125)$ mentioned only two astronomical works of our author; $Z M z$ was not known to him. On the other hand, Rosenfeld and Ihsanoğlu (p.337, No. 1010) listed six astronomical works of Mazharuddīn. Instead of ZMz, another Zīj-i Saghīr Mazhari ( Mazhar's Minor Zijj) is also mentioned, a copy of which is also extant in Tehran ${ }^{93}$ and in which Mazharuddīn mentions that he wrote $Z \bar{l} j-i$ Kabīr Mazharī ( Mažhar's Major Zīj), i.e. ZMz, after completing his Minor $Z \bar{i} j .{ }^{94}$

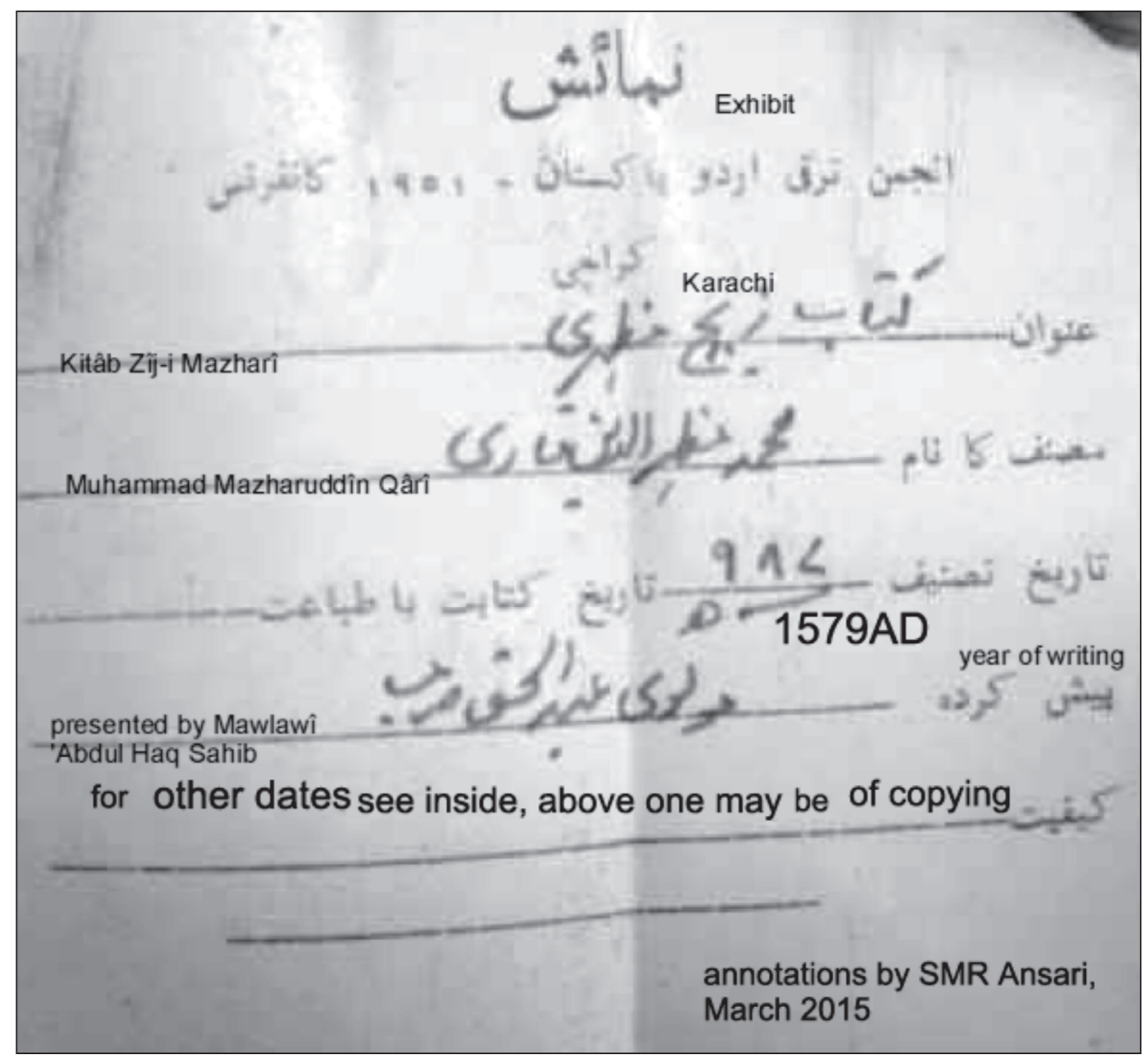

Fig. 2. Title page/Flyleaf of Ms. Kitab Zij-i Mazhari, Courtesy Urdu Promotion Board, Karachi

\footnotetext{
${ }_{93}$ Monzavi (Catalogue,Ms. No. 493, pp. 278-279) who has listed the topics of its chapters along with the list of Mazharuddin's works. However, Monzavi does not mention Mazharuddīn's Commentary on ZUB, which is extant in Asiatic Society (Calcutta) according to Rosenfeld and Ihsanoğlu. In the National Library at Calcutta (Buhār Mss. Collection), his work concerning Qurān is also extant; cf. Storey, Vol.I, Part II, p. 1227. Since almost all his writings are /had been extant in the subcontinent, we are including this $Z \bar{i} j$ in our Survey as an exception, although his base meridian for observations had been Shiraz.

${ }^{94}$ Dalen (2007, p.104, No. C48, C49) mentions these two Zïjes just by a couple of lines. According to him they are extant in AS Library(Calcutta).
} 
The Karachi manuscript is dated AH 987/ AD 1579 (fly leaf / f. 1a). It is incomplete and has 69 folios (138 pages). The first two pages are missing, since the manuscript begins abruptly with the sixth section $(f a s l)$ of the contents. Altogether there are 12 sections (fasl). The last two sections, eleventh and twelfth on fixed stars are not present in this manuscript copy. In the following, the topics of various sections are listed for the first time. ${ }^{95}$ The first few sections of $Z M z$ are on usual astronomical calculations: Mean motions, longitude and latitude of the Sun, Moon and five planets, ascending and descending nodes of the moon; they are actually according to Zij-i Ulugh $B e ́ g$ as mentioned specifically on f.4b. The $Z \vec{i} j$ contains also one section each on solar and lunar eclipses, lunar phases, crescent visibility, appearance and disappearance of planets, lunar mansions and fixed stars. In the subsequent sections, as an aid to astrology - actually the substantial part of $Z M z$--Mazharuddīn has written one section each on : sectors of the orbits (Nițāqāt) and planets' stations (Muqāmāt), determination of conjunctions and opposition, determining all applications ( Ittișālāt) and ingress or entry $(T a h w \bar{l} l)$ of planets in the zodiacal signs. He has dealt with in some details the important astrological parameters and their calculation, e.g., planetary exaltation (Sharaf) and dejection or depression $(H u b \bar{u} t)$. In Islamic astrology, a juxtaposition of planets and zodiacal signs has been in use, in order to define the planetary maximum or minimum influence, namely exaltation (Sharaf in Arabic) respectively depression/dejection (Hubūt) in a horoscope. For instance Sun is in exaltation when it is $19^{\circ}$ in Airy, but in depression $19^{\circ}$ in Libra; Moon is in exaltation when it is $3^{\circ}$ in Taurus, but in depression $3^{\circ}$ Scorpio. ${ }^{96}$ For other parameters, such as conjunction (Ijtimā') and opposition (Istiqbāl), aspect (al-Nazar or Tanāzur), application (Ittisăl), etc. one may refer to Ühlmann (1972, pp. 353-357). The best source for the Arabic-Islamic astrology is actually al-Bīrūnī's treatise : The Book of Instruction in the Elements of the Art of Astrology; see details in the bibliography.

It may be mentioned that Mazharuddīn illustrated his calculations by a few examples, which are dated as 1554,1560-61 and 1565 .

The epilogue (Khätima, f.67a et seq.) concerns with the imaginary, malefic ( Naḥus) pseudo-planet Kaid (the word means deceit), with its backward motion with respect to the succession of zodiacal signs, the period of which is given correctly as 144 years (f. 67b). ${ }^{97}$ On the last f. 69 calculation of its ephemerides for the complete year 928 Yazdigird / AD 1560 are tabulated. On the margin of this folio the longitudes of Kaid 's six companions for the date, 1st Farvardinn 486 Jalālī / AD 1565, are also listed . These tailed companions are Ghatait (meaning snoring), Gharīm, Sar-i Mūsh (mouse's head), Kilāab (dog), Dhū al-Dhawāba (having mane), and Lihyānñ (an Arab tribe). ${ }^{98}$ Finally we may mention that the text of the above-mentioned Hyderabad manuscript is verbatim copy of the Karachi manuscript. We wish to compare these two manuscripts elsewhere. ${ }^{99}$

\footnotetext{
${ }_{95}$ We thank Mr. Rashid Ashraf (Karachi) to procure for us a copy of this unique manuscript.

${ }^{96}$ Cf. Hartner (1975), "The Elements of Hellenistic and Islamic Astrology", p. 220. The whole system of combination is as follows:

$\begin{array}{lccccccccc} & \text { Sun } 19^{\circ} & \text { Moon } 3^{\circ} & \text { Saturn } 21^{\circ} & \text { Jupiter } 15^{\circ} & \text { Mars } 28^{\circ} & \text { Venus } 27^{\circ} & \text { Mercury } 15^{\circ} & \text { Rahu } 3^{\circ} & \text { Ketu } 3^{\circ} \\ \text { Exaltation } & \text { Airy } & \text { Taurus } & \text { Libra } & \text { Cancer } & \text { Capricorn } & \text { Pisces } & \text { Virgin } & \text { Gemini } & \text { Sagittarius } \\ \text { Dejection } & \text { Libra } & \text { Scorpio } & \text { Airy } & \text { Capricorn } & \text { Cancer } & \text { Virgin } & \text { Pisces } & \text { Sagittarius } & \text { Gemini }\end{array}$

${ }^{97}$ For detailed history of the concept of Kaid, see Kennedy (1957) and his Arabic sources.

${ }^{98}$ Cf. Kennedy(1957), pp. 48-49. We use his vocalization, but copy the names from our manuscript, e.g. Gharīm and not 'Azīm (the great) as given in Kennedy's paper.

${ }_{99}$ We thank Mr. Aneesul Hasan Siddiqi (Gurgaon) for procuring us with many pages of the Hyderabad manuscript.
} 


\section{4. Ż̄JES BASED ON ANCIENT INDIAN Astronomy}

The above mentioned Zījes belong to a specific class of astronomical literature, since their underlying principle is Ptolemaic model of planetary motion. We have discovered also in Indo-Persian literature another class of astronomical tables, also titled Zijes, which however are actually based on the Indian Siddhāntic astronomy. That is, they are Persian translation or adaptation from the Sanskrit Siddhāntas (treatises on theoretical astronomy) or Karanas (manuals of astronomical calculations). Their manuscript copies, extant in Indian and Pakistani libraries, are listed in the following.

1. Zīj-i Muzaffarshāhī (1525), anonymous. One manuscript is in the Shīrānī Collection, PUL (Lahore), scribed by Gul Muhammad. We discovered another anonymous manuscript in Raza Library (Rampur), in a codex No. 1185, entitled Risālah dar Hay'at.

2. Zīj-i Āsaf Jāhh̄ (18th c.), copied by Imāmuddīn Riyādī (d. 1732), elder brother of Khairullāh Muhandis. It is dedicated to Nizāam al-Mulk Āṣaf Jāh (reign1720-1748), the first Nizām of the state of Hyderabad (Deccan). The manuscript, No. US 78(4421), is extant in the SJM Library (Hyderabad).

3. Zìj-i Nizāamm̄ (1780) by Bahādur Husayn Khān is dedicated to the fifth ruler of Hyderabad, Nawāb Nizāam 'Alī Khān (reign 1762-1802). Two manuscripts of this $Z \bar{l} j$, No. Riya $\bar{a} \bar{l}-112$ with $236 \mathrm{ff}$. and Riy $\bar{a} \underline{\underline{\imath}}-296$ with 207ff., are extant in A. P. Govt. Oriental Manuscripts Library (Hyderabad).

4. Zīj-i Sarūman̄ (1797), i.e., the Siddhānta Siromaṇ̄ by Bhāskara II (12th c.), was translated by Khwājah Șafdar 'Alī Khān, and is dedicated it to Arasțū Jāh. (d.1804), the prime minister of Hyderabad. The translator gives this information in the opening folio (1b) of his another work, Zīj-i Safdarī, see below no. 7. No copy of this translation has been found to-date.

5. Zīj-i Hindī (1804/5) was compiled by Gul Bég Munajjim (the astronomer) bin Zaynul 'Ābidīn, grand son of Khairullah Muhandis. Only two manuscripts of this $Z \bar{i} j$ are extant, one in Raza Library (Rampur), Ms. No.1221, ff.106-130 bound with the manuscript of $Z \bar{i} j-$ $i$ Muhammad Shāhī; the second in the National Museum (Karachi, Pakistan), Ms. No.1959-409/2, ff.148-176.

6. Zīj-i Mìr 'Ālamī (1807/8) by Șafdar 'Alī Khān bin Muhammad Husayn Khān is dedicated to Nawāb Mīr Abu'l Qāsim alias Mīr ‘Ālam (d.1808), who was the Prime Minister of Nizām of Hyderabad. Its unique manuscript, Riya $\bar{d} \bar{l}-301$ with $162 \mathrm{ff}$., is extant in A. P. Govt. Oriental Manuscripts Library (Hyderabad) .

7. Zīj-i Safdari (1819) is authored again by Șafdar 'Alī Khān bin Muhammad Husayn Khān. The unique manuscript, No. Hay'at15 with 183 ff., apparently an autograph copy is extant in SJM Library( Hyderabad ).

8. Zījj-i Tālpar (1835) by Sulțān 'Alī Baloch bin Sa'īd Khān alias Tālpar is extant in Madrasa Rāshidyah, Khairpur (Pakistan). ${ }^{100}$

9. Zīj-i Sulaymān Jāhī (1839) was compiled by Sayyid Rustam 'Alī Raḍwī, who had been a pupil of Śrī Dhar Pandit, (resident of Jawār,district Banaras) and also of Muftī Blīgh al-'Ālam Khān (resident of Murshidābād). Rustam 'Alī dedicated his $Z \bar{l} j$ to the ruler of Awadh, Nașīruddīn Haydar (reign 18271837). A unique manuscript of this $Z \bar{i} j$, No.1229 with 77 ff., is extant in Raza Library (Rampur) and is scribed by Muhammad Akbar Shāhjahānābādī for Muftī Sharfuddīn Rāmpūrī.

\footnotetext{
${ }^{100}$ Monzavi, p. 276, No. 1595. It is mostly on calendars, deals also with Nakṣatras and Yoga etc. No more details are available presently,
} 
Our detailed studies (Ansari 2009b) show that these works are actually based on the Sanskrit works by Bhāskara II (12th c. ), Śatānada (fl.1099) of Pūrī, Makranda Ānandakanda (fl.1478), Appaya son of Marla Perubhatta (fl. 1491), Ganeśa Daivajña of Gujarat (fl.1520/1554), Rāmabhața (fl.1590), Rāghavānanda Śarman (fl. 1591/1599), Mathurānātha Śarman (fl. ca.1609), and Narasiṃha son of Kāpurī (fl. 1687-1747).

\section{Concluding Remark}

Notwithstanding the above-mentioned $Z \overline{i j}$ es, the manuscript collections in the erstwhile subcontinent contain also copies of standard $Z \bar{l} j e s$ in Arabic and Persian languages. We have already mentioned above $Z \bar{i} j-i$ Ulugh Beg with many extant copies. The other important $Z \bar{i} j e s$ are as follows. $^{101}$

1. Zīj-i Safāih by Ja'far al-Khāzinī (d. 10th c.). We discovered its unique complete copy in Iqbal Library, Kashmir University, Srinagar.

2. Zīj-i Kushyār al-Jīlī by Kushyār Ibn Labbān (d.1030), Ms. in SCL (Hyderabad).

3. Zìj-i al-Mu 'tamad al-Rașadiyah (1166) by 'Alī bin 'Abdul Karīm al-Bākūhī, Ms. in SJM (Hyderabad).

4. Zīj-i Ilkhāni by Naṣīruddīn al-Ṭūsī (d.1274), mss. in SCL (Hyderabad), CP(Jaipur), and MF (Bombay).

5. Zìj-i Tūnisì by Abu'l 'Abbās Ibn Ishạa alTūnisī (fl. 13th c.), unique manuscript copy in CSL (Hyderabad), copy of AD1317. ${ }^{102}$
6. Zīj-i Khāqānī by Jamshīd Ghiyāthuddīn alKāshī (d. 1430), mss. in SCL (Hyderabad )and CP (Jaipur).

7. Zīj-i Mulakhkhas Mirzā’ ̄̄ by 'Abdul Qādir bin Hasan Rūyānī Lāhìj̄̄ (d.1519), with one Ms. in Zakir Husain Library, Jamia Millia Islamia (New Delhi). ${ }^{103}$ Another Ms. Astr.50/1 is in MF (Bombay) .

8. Zīj-i Khānī by Nașīruddīn Haydar (13th-14th c.), Ms.in RL (Rampur).

9. Zīj-i Quṭ̂i fì 'Ilm al-Nujūm by Quṭb 'alā Lațīf, Ms. in SJM (Hyderabad), copy of 1584 and scribed by 'Abdul Latîif bin Sulțan 'Alī Kashmīî̄. ${ }^{104}$

It is not claimed that this list is comprehensive. However, the most important Zìjes are included here.

We wish to conclude by the remark that the Islamic Astronomy was transmitted extensively into Medieval India through the medium of Indo-Persian language, which was the over all language of erstwhile Indian Subcontinent. Actually it was the language of all disciplines, particularly also of sciences as we understand it today. Manuscripts libraries in India, Pakistan and Bangladesh possess a large number of scientific manuscripts both in Arabic and Persian. The body of knowledge contained in this class of IndoPersian literature gave rise later also to original writings in exact sciences as well. As an example we mention here the name of historian and poet, Raja Ratan Singh of Bareilly (d.1851), who wrote in 1837 Hadā'iq-ul-Nujūm (Gardens of

\footnotetext{
${ }^{101}$ We mention here only the mss. available in the libraries of the subcontinent. For other manuscripts see catalogues by Storey (1972), Rahman et al. (1982), King and Samso (2001) and Benno v. Dalen (2007)

${ }^{102}$ King and Samso (2001), p. 60, cf .also King and Samso (2002), p. 508, col.I, for further reference, esp. for the doctoral dissertation by A. Mestres (Barcelona) 2002.

${ }^{103}$ We thank Mr. Ghayas Makhdumi, the Librarian of Jamia Millia Islamia (N. Delhi) for procurement of this $Z \bar{i} j$.

${ }^{104}$ This $Z \vec{j}$ is not mentioned in the catalogues referred above, although it is clearly listed in the SJM Catalogue, Vol. IX (1988) p. 233, No. 3381. Thanks are due to the director of SJM for providing us with a digitized copy. We intend to publish its study elsewhere.
} 
Astronomy) in Persian by the order of Nawāb of Awadh, Nașīruddawlah alias Muhammad 'Alī Shāh. This treatise of 1158 pages is on modern mathematical astronomy. It was lithographically printed by Muhmmad Hussain at Muhmmadī Press (Lucknow) in a few editions: in 1837, 1841 and $1843 .{ }^{105}$ It is high time that all this literature is brought to light and studied seriously as our scientific heritage.

\section{ACKNowledgment}

The author acknowledges here gratefully a three months Visiting Fellowship of Alexander von Humboldt Foundation (Bad Godesburg, Germany) in 2007. Thanks are due to Prof. David
King (Frankfurt) for support and Dr. Benno van Dalen (Frankfurt) for many friendly discussions. $\mathrm{He}$ is also indebted to Drs. Mahmūd Mar'ashī (Qum), Ashraf Akhmedov (Tashkent), Dr. Mohammad Bagheri (Tehran) and Dr. Farid Ghassemlou (Tehran) for generous presentation of their publications frequently. We are also indebted to the Directors of Salar Jung Museum, A.P. Govt . Manuscript Library and Research Institute (Hyderabad) and the Librarian of Jamia Milliia Islamia (New Delhi) for providing us with manuscripts on urgent request. Thanks are also due to my friends Rashid Ashraf (Karachi) and Aneesul Hasan Siddiqui (Gurgaon) for their cooperation.

\section{Appendix I}

\section{List of Symbols for Libraries or Collections}

ANM Āyat Allāh Najafī Mar'ashī Library, Qum.

AS Library of the Asiatic Society (formerly of Bengal), Calcutta.

CP Raja Man Singh (City Palace) Museum Library, Jaipur

CRL K.R. Cama Research Library and Oriental Institute, Bombay

IO Indian Office Library, London.

KhB Khuda Bakhsh Oriental Public Library, Patna (formerly known as Bankipur).

Lahore Punjab University Library (PUL), Punjab Public Library (PPL), Lahore (Pakistan).

MAL Maulana Azad Library, Aligarh Muslim University, Aligarh.

MF Mullā Fīroz Collection in K.R. Cama Research Library, Bombay.

MW Madrasatul Wā'izīn (Lucknow).

NU Library of the Nadwatul 'Ulamā', Lucknow.

OUL Osmania University Library, Hyderabad.

RL Raza Library, Rampur.

SCL State Central Library, formerly Așafiyah, Hyderabad. The Mss. are now housed in A.P. Govt. Oriental Manuscripts Library and Research Institute, Hyderabad.

SJM Salar Jang Museum Library, Hyderabad.

SL Sa‘̄idiyah Library, Hyderabad.

\footnotetext{
${ }^{105}$ For the importance and originality of this treatise, cf. Ansari (2004).
} 


\section{Appendix II: Persian Text}

(Sa'd Salmān): A1

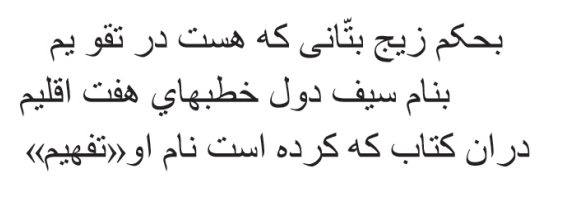

جو سال هجرت بحذشت تى وسين و سه جيم
هنجمان همه كفتند كاين د ليل كند كهد دير و زود خطيبان كنند بر منبر

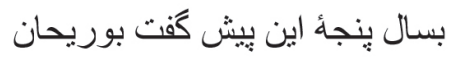

كه بادشاهى صاحبقر آن شود يِيدا

(Ṭahir Khān , p. 212) : A2

...تخت مرصتع مسقف مشتمل بردوازده ستون... و جواهر هشتاد وشش لك روبيه ويك توله طلا صرف آن شده...و از جمله جو اهر آن لعلى است كه شاه عباس صفوى بر ائ جنت مكانى [جهانكير] ارسال داشته بود بر آن نام نامى حضرت صاحبقز [ شاهجهان] وميرز اشاهز خ و ميرز الغ بيع و شاه عباس و جنت مكانى و عرش آشيانى [ اكبر] و بندكان

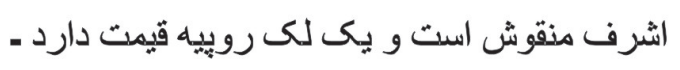

$(Z R$, fol.2a $): \mathrm{A} 3$

زيج رصدى آنر اكويند كه حكماى تجربه كار ور اصدان نامدار از روى قو اعد وآلات بجهت ضبط اين كار كرده اند ...

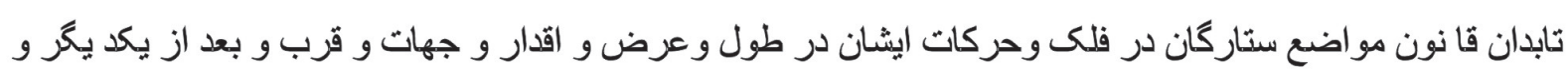

اوضاع (ورق 2 b ) هر يك به نسبث زمين وانجه بدان مانند باثد تدقيق نموده در كتابع مضبوط كردانند و زيج

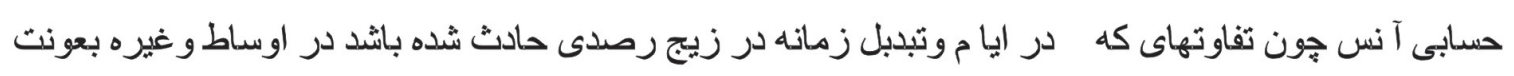
حساب بقدر امكان درست سازند وخطا هائ كه بقلم نا سخان بوقوع آمده باشد تصديح نمايند ـ

(Ṭahir Khān , p. 82): A4 ودراين ايام زيج حسابى موسوم به زيج شاهجهانى كه به حسن سعى يمين الدوله آصف خان و وحيد دوران، ملا فريد به اتفاق

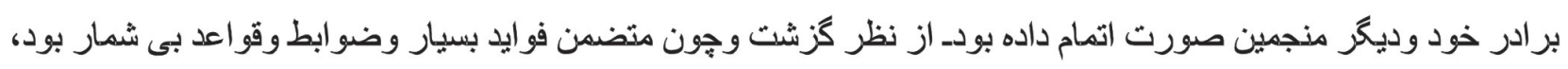

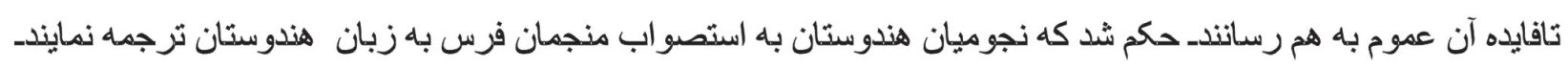
جنانجه قبل از اين تقاويم از زيج ميرزا الغ بيكى استخر اج ميكردند ،حالااز اين زيج به آسانى استنباط مى نمايند.

(Sangīn Beg, pp.117-118): A5

و حال جنتر منتر اين است كه مرزا خير لله و سه هنود ديكر ساكنين جى بور ، شريك بودندو حسب كفته نيار نمودند ...

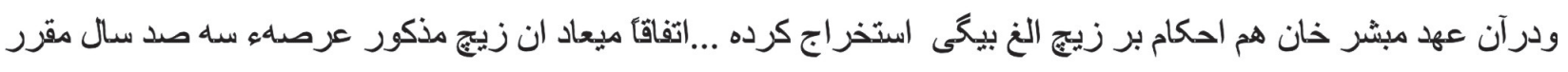

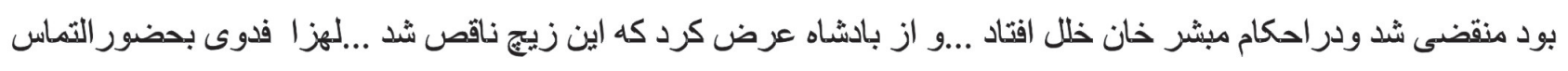

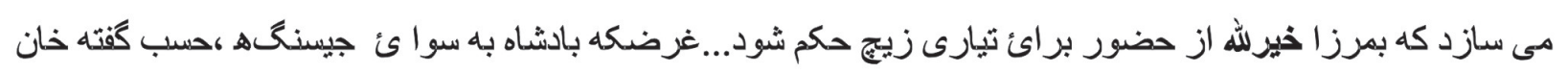

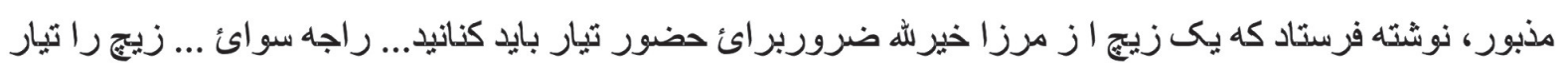
كنا نيده...بادشاه ان زيج به مبشر خان حو اله نمود ـ خان مذبور بدان زيج استخر اج احكام مينمودند ومطابق مي شنيد ويكسر موتخالف درحكمها نميشد- 


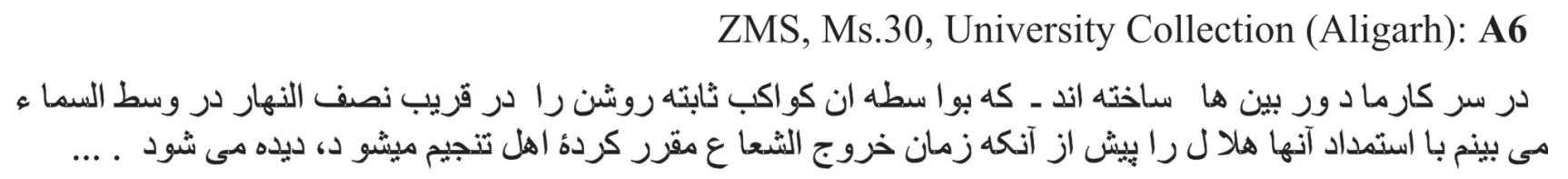

\section{BIBLIOGRAPHY}

Abdullah Zade, K. F. "On Some Zijes by Scholars of the Near and the Middle East", Studies in History of Medicine and Science (New Delhi), Vol, X-XII (198687), pp. 183-190, with notes by S.M.R. Ansari. Translated into English by Shameem Bano from the Russian original published in, Otdelenie Obshestvenniikh Hayk (Tajikstan), Vol. 95.1(1979):11-16.

Abū'l Fadl 'Allāmī (16 $6^{\text {th }} \mathrm{c}$.). The A'' '̄n-i Akbarì (Institutes of Akbar), translated into English by H. Blochmann, Bibliotheka Indica, No. 6. Reprint, Calcutta, 1927.

Abū'l Faḍl 'Allāmī (16th c.). The Akbar Nāmā, translated into English by H. Beveridge, in 3 volumes. Reprinted, Delhi 1972. Persian text Originally published from Calcutta in 1877.

Ansari, Nurul Hasan. Ma'āthir-i Mahmūed Shāhī. Delhi University, Delhi, 1968.

Ansari, S. M. Razaullah and Zia, Fatima. An Essay Review on Science and Technology in Medieval India, by A. Rahman et al., Studies in History of Medicine, New Delhi, Vol. VIII, No.1-2, (1984):67-87

Ansari, S. M. R. "The Observatories Movement in India during the $17^{\text {th }}-18^{\text {th }}$ Centuries", Vistas in Astronomy, Vol.28, (1985a):379-385.

Ansari, S. M. R. Introduction of Modern Astronomy in India during $18^{\text {th }}-19^{\text {th }}$ Centuries, Indian J. of History of Science, Vol. 20, chapter 12, 1985b, pp. 363-402. This chapter has also been issued as a separate monograph with the same title and with a foreword by Hakeem Abdul Hameed, IHMMR (presently Hamdard University) Hamdard Nagar, New Delhi, 81pp. Here we refer to the chapter in IJHS.

Ansari, S.M.R. "Ghulām Ḥusain Jaunpūrī and his $Z \bar{i} j-i$ Bahādurkhān $\vec{\imath}$, Studies in History of Medicine \& Science (New Delhi), Vol. XVI, No. 1-2, New Series, (1995/96): 181-188.

Ansari, S. M. R. On the Transmission of Arabic-Islamic Astronomy to Medieval India. Archives Internationales d'Histoire des Sciences, 45, No.135 (1995):273-297.
Ansari, S. M. Razaullah (Ed.). History of Oriental Astronomy (Proceedings of the IAU Joint Discussion-17, held in Kyoto (Japan) Aug.25-26, 1997). Astrophysics and Space Science Library, Vol. 274, Kluwer Academic Publisher, Dordrecht (The Netherlands), 2002, 282 pages. Distributed now by Springer Business, Dordrecht.

Ansari, S.M.R. and Sarma, S. R. Ghulām Ḥusain Jaunpūrī and his Encyclopaedia of Sciences, Studies in History of Medicine and Science (New Delhi), Vol. XVI, No. 1, 2 New Series, 1999/2000, pp.77-93.

Ansari, S.M.Razaullah. Rāja Ratan Singh Zakhmī - A Litterateur, Historian and An Astronomer of 19th Century, Proceedings of the International Seminar on Contribution of Persian Language and Literature to the Composite Culture, Ed. Azarmi Dukht Safavi, Persian Dept. AMU, Aligarh, 2004, pp. 129-138.

Ansari, S.M.Razaullah. Hindus' Scientific Contributions in Indo-Persian, Indian J. of History of Science, 40.2, (2005):205-221.

Ansari, S.M.R. "On Ghulām Ḥusain Jaunpūrī and his Works", (in Persian). Invited article, published in The Encyclopaedia of the World of Islam (Dānishnämahi Jahān-i Islām ), edited by Golām 'Alī Haddād 'Ādel,Tehran. Vol. 11, 2007, pp. 387-389. Persian translation of the article by Farid Ghassemlou.

Ansari, S. M. R. "Promotion of Exact Sciences During the 14th-15th Centuries", in Persian Literature in Sultanate Period, Ed. Maria Bilquis, Dept. of Persian, Aligarh Muslim University, Aligarh, 2008a, pp. 6072.

Ansari, S.M.R. "Jai Singh Sawā'i" (in Persian), The Encyclopaedia of Persian Language and Literature in the Subcontinent. Managing Editor, Ali Mohammad Moazzani. The Academy of Persian Language and Literature, Tehran. Vol. II, 2008b, pp. 1228-1230. Revised English version will be published shortly.

Ansari, S. M. R. "The Transmission of Ulugh Beg's School of Astronomy to Medieval India and its Impact on the Development of Indian Astronomy", Paper read at the conference on Contribution of Mirza Ulugh Beg to the World Science, dedicated to the 615th Anniversary 
of Mirza Ulugh Beg, held June 9-11, 2009a, Tashkent (Uzbekistan).

Ansari, S.M.R. " Reception of Indian Astronomical Treatises and Handbooks in Sanskrit by Muslim Scholars of Medieval India", in Astronomy, Astrology, Mathematics and the Physical World, ed. J.V. Narlikar, Vol. IV, Part 8 of the Project of the History of Indian Science, Philosophy and Culture. General editor, D.P. Chattopadhyaya, Chapter 8, 2009b, pp.251-274. New Delhi.

Ansari, S.M. R. "On Khairullāh Khān Muhandis" (in Persian), published in Encyclopedia of the World of Islam ( Dānishnāmah -i Jahān-i Islām), edited by Golām 'Alī Haddad 'Adel, Tehran, Vol. 16, 2011, pp. 608-611.

Ansari, S. M. Razaullah, "The Compilation of Zijes in India" (in Persian). published in the Encyclopaedia of Persian Language and Literature in the Subcontinent. Editor, Muhammad Reza Nasiri, The Academy of Persian Language and Literature, Tehran, Vol. III (2013):533536. The present article is a substantially revised version of this Persian one.

Ansari, S.M.R. "On Indian Astronomer Ghulam Husain Jaunpuri", in Encyclopedia of History of Science, Technology and Medicine in Non-Western Cultures, Ed. Helain Selin, Dordrecht. Springer Science, 2015. Second edition.

Bahura, G.N. Catalogue of Manuscripts in the Maharaja of Jaipur Museum, Jaipur, 1971.

(al-) Battān̄̄, Abū ‘Abdallāh Muhammad bin Jābir (ca.912), $Z \bar{j}$ al-Șa $b \vec{\imath}$. The Arabic text was edited with translation and commentary both in Latin by the Italian Orientalist Carlo Alfonso Nallino (d.1938), in three parts with the title, Al-Battānī sive Albatenii opus astronomicum. Milano (Ulrico Hoepli) 1899-1907. Part I-II reprinted by Fuat Sezgin, Frankfurt a.M. 1969.

To note is that this rare publication in three parts is accessible in the Reserve Section of M. A. Library, Aligarh Muslim University, Aligarh.

(al-)Bīrūn̄i, Abu'l Rayḥān Muḥamamd (1029), Kitāb alTafhìm li Awā'il Șinā'a al-Tanjīm ( The Book of Instruction in the Elements of the Art of Astrology), translated from Arabic into English by R. Ramsay Wright, London, Luzac \& Co. 1934. Reprinted and published by Fuat Sezgin, Vol. 29 of Islamic Mathematics and Astronomy Series. Publications of the Institute for the History of Arabic-Islamic Science, Frankfurt am Main, 1998.
Calvo, L. Emilia. Abu' 1 Fidā', in Encyclopaedia of the History of Science, Technology, and Medicine in NonWestern Cultures. Editor, Helaine Selin, pp. 7-8. Dordrecht, 1997. Kluwer Academic Publishers. The second edition is in press now.

Chatterjee, S.K. and Chakravarthy, A.K. "Indian Calendar from Post-Vedic Period to AD 1900", Indian J. of History of Science, Vol.20 (1985): 252-307.

Dalen, Benno van. " Origin of the Mean Motion Tables of Jai Singh", Indian J. of History of Science, 35.1, (2000):41-66.

Dalen, Benno van. “The Zīj-i Nāsirirī by Mạ̣mūd ibn 'Umar. The earliest Indian-Islamic astronomical handbook with tables and its relation to the 'Alä' $\bar{\imath} Z \bar{i}$ '”, in Charles Burnett et al. Studies in the History of of the Exact Sciences in Honour of David Pingree, Brill, Leiden, (2004):825-862.

Dalen, Benno van. “A New Survey of Islamic Astronomical Handbooks, with Description of more than 200 Arabic and Persian Zijes". Preliminary Version. To be published after revision in the Proceedings of the American Philosophical Society. Philadelphia, 2007.

Farishta, Muhammad Qāsim Hindū Shāh. Tārīkh-i Frishtah (in Persian), English translation by John Briggs, The History of the Rise of the Mahomedan Power in India, ( Chapter on Sooltan Mahmood Khiljy), Vol. IV, Calcutta, 1971,pp. 117-142. Reprint of the first edition, London, 1829.

Fikrat, Muhammad Āṣif, Fihrist-i Alfabà'̄ Kutub-i Khațtī, Kitā̇̉khāna'-i Markaz̄̄ Āstān-i Quds Raḍaw̄ (Alphabetical Catalogue of Manuscripts), Mashhad. Publication Division of the Library of Holy Shrine, No. 12, 1991, p. 299.

Forbes, Eric G. “The European Astronomical Tradition, its Transmission into India, and its Reception by Sawai Jai Singh II", Indian Journal of History of Science (New Delhi), Vol. 17(1982):234-243.

Ghori, S. A. Khan, "The Perspective of the Revival of Rationalism ('Aqliyāt) in India" (in Urdu), Majalla'-i 'Ulūm-i Islāmiya, Aligarh Muslim University. 1969, Issue of June-December.

Ghori, S. A. Khan. "Development of Zīj-Literature in India", Indian Journal of History of Science, Vol.20, (1985): $21-48$.

Ghulām Husain Jaunpūrī. Jāmi ' Bahādurkhān̄̄ (Encyclopaedia of Sciences), in Persian, lithographically printed in Calcutta. 1830- 1835, 720 pages. Reprinted by Azad University (Tehran 2008), with a foreword by Farid Ghassemlou. 
Ghulām Husain Jaunpūrī. Kitāb Ifādāt-i Nișāb, Zìj-i Bahādurkhān̄i, calligraphist Pandit Shiv Prashad ( with nom de plume Khākī) and printed at Cadre (Kādar) Press, Banaras 1858.

The Copy in Salar Jang Museum, Library (Hyderabad),1855-58, contains 906 pages. Reprinted in 2009 with a foreword by Farid Ghassemlou, Azad University, Tehran.

Gravious, Johannes. Zij Ologhbeik. Reprinted in 2008 with an introduction by Farid Ghassemlou. Azad Islami University, Tehran. The original text was published in London 1650. It is the Latin translation of the first Maqāla. Cf. Also Sédillot (1847), below.

Greaves, John. Astronomica quaedam ex traditione Shah Cholgii Persae. Una cum hypothesibus planetarum. Fleisher, London, 1650.

Hartner, Willy. The Elements of Hellenistic and Islamic Astrology, reprinted in Oriens-Occidens, Vol. II, 1984, Ed. Y. Maeyama, George Olms Verlag, Hildesheim (Germany), 218-217.

(van) Helden, A. "The Telescope in the Seventeenth Century", ISIS, Vol. 65(1974):38-58.

Ḥusaynī, Ahmad and Mar'ashī, Maḥmūd. Catalogue of the $\bar{A}$ yat Allāh al-'Uz mā Najafì Mar' ashī Public Library, Qum, Iran, 1994,Vol. XXIII.

Kennedy, E.S. "A Survey of Islamic Astronomical Tables", Transaction of the American Philosophical Society. New Series, Vol. 46/2, 1956, pp.123-177. Persian translation by M. Bagheri (Tehran), 1995.

Kennedy, E.S., Comets in Islamic Astronomy and Astrology, J. of Near Eastern Studies, Vol. 16/1, 1957, pp. 4451.

Khairullaev, M. M., Bulgakov, P.G., Ahkhmedov, A. et al., Mlūghbek Muhammad Tarāghā' $\bar{\imath}$ (1394-1449), His Life and [his] Zīj-i Jadìd Gūrgānī, in Russian . Publisher, Uzbekistan Academy of Science and Abu Rayhan Biruni Institute of Oriental Studies, Tashkent, 1994.

King, David A. Astronomy in the Service of Islam, Collected Studies Series, Variorum Reprints, Aldershot, 1993, 333 pages.

King, David A. and Samso, Julio. "Astronomical Handbooks and Tables from the Islamic World (750-1900): An Interim Report" (with a contribution by B.R. Goldstein), Suhayl (Barcelona), Vol.2 (2001), pp. 9105.
King, David A. and Samso, Julio. "The Scope, Overview and Content of the Zij Literature", in Encyclopaedia of Islam, second edition,. Vol. 11, (2002):497-508, Brill, Leiden.

Mercier, Raymond. "Account of Joseph Dubois of Astronomical work under Jai Singh Sawai “, Indian Journal of History of Science, Vol. 28(1993):157-166.

Orthmann, Eva. "Circular Motions: Private Pleasure and Public Prognostication in the Nativities of the Mughal Emperor Akbar", in Günther Oestmann, H. Darrel Rutkin and Kocku von Stuckrad (Eds.): Horoscopes and Public Spheres: Essays on the History of Astrology, (2005):101-114. Walter de Gruyter, Berlin \& New York..

Pingree, David. The Astronomical Works of Gregory Chioniades. Vol.I, The Zīj Al-'Alā' $\bar{l}$. Part 1,Text, Translation, Commentary. Part 2, Tables. J.C. Gieben, Amsterdam, 1985-86, [Corpus des Astronomes Byzantins, II, General Ed. Anne Tihon].

Pingree, David. "Indian and Islamic Astronomy at Jayasimha's Court", in D. A. King and G. Saliba (Eds.), "From Deferent to Equant, A Volume of Studies in the History of Sciences in the Medieval Near East in Honor of E.S.Kennedy", Annals of the New York Academy of Sciences, Vol. 500 (1987): 313-328.

Pingree, David. "Philippe de La Hire at the Court of Jayasimha", in Ansari, S. M. R. (Ed.) History of Oriental Astronomy, (2002 a):123-131.

Pingree, David, "Philippe de La Hire Planetary Theories in Sanskrit," in Y. Dold Samplonius, J. W. Dauben, M. Folkerts and B. van Dalen (Eds.). From China to Paris: 2000 Years' Transmission of Mathematical Ideas. Boethius Texts. Stuttgart, Franz Steiner Verlag, Vol. 46 (2002 b): 429-453.

Rahman, A., Alvi, M.A., Khan, S. A. Ghori and Murthy, K.V. S. Science and Technology in Medieval India A Bibliography of Source Material in Sanskrit, Arabic and Persian, Indian National Science Academy, New Delhi, 1982. This Catalogue comprises separate sections on Mathematics and Astronomy, Medicine etc. See the review by Ansari and Fatima (1984).

Rampur, Catalogue of Persian Manuscripts of the Raza Library, Vol.1. Published by W.H. Siddiqui. Rampur (India), 1996 .

Rehatsek, E. Catalogue Raisonné of the Arabic, Persian and Turkish Manuscripts in the Mulla Firuz Library, Bombay, 1873. 
Riazul Islam. Indo-Persian Relations, A Study of the Political and Diplomatic Relations between the Mughul Empire and Iran, published by Iran Cultural Foundation (Tehran), printed at Lahore, 1970.

Rizvi, S. Aftab Husain. “ Seth Ward and Ghulam Hussain’s Problem for determining the Place of a Planet", Indian J. of History of Science, Vol. 24.2 (1989): 95-102.

Rosenfeld, Boris A. and Hogendijk, Jan P. “A Mathematical Treatise written in the Samarkand Observatory", $Z$. für Geschichte der arabisch-islamischen Wissenschaften, Vol. 15(2003): 25-65.

Rosenfeld, Boris A. and Ihsanoğlu, Ekmeleddin, Mathematicians, Astronomers, and Other Scholars of Islamic Civilization and their Works (7th-19th c.). Istanbul. Research Centre for Islamic History Art and Culture (IRCICA), 2003, 833 pages.

This catalogue is actually a revised and updated edition of Vol 2 of the catalogue by Matvievskaya, G. P. and Rosenfeld, B. A., Mathematiki Astronomy Musul'manskovo i Crednevskov'ya i ix Trudy (VIIIXVII Centuries), 3 Volumes, in Russian, Izdatel'stvo Nauka, Moscow, 1983. It is an excellent source of information on Islamic exact science. Thanks to late Boris Rosenfeld, who presented me this valuable set.

Salar Jung. Catalogue of the Persian Manuscripts in the Salar Jung Museum Library, Vol. IX, containing astronomy and mathematics. New Series, No. 9/12. First Edition. Compiled by Maulānā Hājī Muhammad Ashraf, and with a preface by Dr. M. L. Nigam (Director). Hyderabad, 1988 (A. P.) India.

Salmān, Mas'ūd Sa'd. Dīwān (Collection of Poems) in Persian, Ed. Rashīd Yāsmī, Fīrūz Press, Tehran, 1961.

Sangīn Bég, Mirzā. Sayr al-Manāzil (A History of Monuments, Mosques, and Important Buildings of Delhi), in Persian, written ca. 1819-1820. Edited Persian text with Urdu translation by Sharif Hussain Qasmi. Ghalib Institute, New Delhi 1982. We have referred to this text edition above. An earlier Urdu translation was carried out also by Na 'īm Ahmad, $A d b \bar{\imath}$ Academy, Aligarh, 1980.

Sayili, Aydin. The Observatory in Islam, Publication of the Turkish Historical Society, Series VII, No.38. Istanbul, 1960.

Schofield, Christine J. Tychonic and Semi-Tychonic World Systems, Series: The Development of Science, Sources for the History of Science, Eds. Michael Hoskin et al. Arno Press, New York, 1981.
Sédillot, Louis P. E. Amélie. Prolégomènes des Tables Astronomiques d'Oloug-Beg. Publiés avec notes et variantes et précédés d'une introduction. Paris (Firmin Didot), édition 1847, Traduction et commentaire, 1853. Cf. also Gravious, J. (1650) above.

Shāhnawāz Khān, Șamṣāmuddawlah (1888/1968), Ma'àthirul Umarā' (A Dictionary of Nobles), in four volumes. The Persian text was published by Asiatic Society of Bengal, Calcutta (now Kolkata), Vol. 1. Urdu translation of the same by Ayyūb Qādrī, published by Markazī Urdu Board, Lahore, 1968. We refer to this translation. English translation by Henry Beavridge and later by Beni Prashad was published in 2 volumes in 1941 and 1952 respectively.

Sharma, V.N. "Jai Singh, His European Astronomers and the Copernicus Revolution", Indian Journal of History of Science (New Delhi), 17(1982): 333-344.

Storey, C. A. Persian Literature. A Bio-bibliographical Survey, Vol. II, Part 1. Luzac \& Co, London, 1972. Reprint. First printed in 1958.

Ṭāhir Khān alias 'Ināyat Khān, Mīrzā Muḥammad (17th c.), Mulakhkhaș-i Shāhjahān Nāma (Extracts from the History of Shahjahan) critically edited by Jameelur Rehman (Delhi University), with an introduction and annotations. Centre for Persian Research, Iran Cultural House, New Delhi 2009.

It is actually an abridgment partly of $P \bar{a} d \operatorname{sh} \bar{a} h N \bar{a} m \bar{a} h$ by 'Abdul Hamīd Lāhorī (d. 1655).

Taqizadeh, Hasan. Gāh-i Shumārī dar Irān-i Qadīm (Calendar in Ancient Iran) . Tehran, 1938. Printed at the Majlis Press.

Ullmann, Manfred, The Natural and Occult Sciences in Islam (in German). Series: Handbuch der Orientalistik, Ed. B. Spuler. Supplement Volume VI, part II, Leiden, Brill, 1972. Chapter 5, Die Astrologie, pp. 353-357.

Wright, R. Ramsay and Wiedemann, Eilhard (1926-27), "Über die Schrift, Astronomica quaedam von Greaves", originally published in Sitzungsberichte der Physikalisch-Medizinischen Sozietät zu Erlangen, Bd. 58-59, pp. 381-386. Reprinted in E. Wiedemann, Aufsätze zur Arabischen Wissenschaftes Geschichte, Vol. II, "Beiträge zur Geschichte der Naturwissenschaften”, LXXVII, pp.695-700. Hildesheim, 1970. George Olms Verlag.

Young, Gregg de, “John Greaves' Astronomica quaedam, Orientalism and Ptolemaic Cosmography in the Seventeenth Century England", Indian J. of History of Science, 39.4 (2004): 467-510. 